$\mathrm{K}$

STUDIA Z PRAWA WYZNANIOWEGO

Tom $22-2019$

DOI: https://doi.org/10.31743/spw.4795

GRZEGORZ MAROŃ*

\title{
ODWOŁANIA DO BOGA W KONSTYTUCJACH PAŃSTW WSPÓŁCZESNYCH. STUDIUM KOMPARATYSTYCZNE
}

\section{Streszczenie}

W artykule przedstawiono rezultaty ilościowo-jakościowego komparatystycznego studium konstytucji państw współczesnych pod kątem obecności w nich bezpośrednich odniesień do Boga. Odwołania do Boga występujące w ustawach zasadniczych blisko $2 / 3$ państw globu posiadają różną postać językową i pełnią kilka funkcji. Najczęściej przybierają formę invocatio lub nominatio Dei w preambułach oraz pojawiają się w rotach przysięgi funkcjonariuszy publicznych, rzadziej są natomiast udziałem innych postanowień konstytucji, np. tych określających oficjalne symbole państwowe, jak flaga, hymn czy godło. Odwołania do Boga w ustawach zasadniczych nie mają wymiaru teologicznego, lecz stanowią przejaw responsywności ustrojodawcy wobec przekonań i wierzeń obywateli o Bogu. W ocenie autora, decyzja o zamieszczeniu, niezamieszczeniu lub usunięciu odniesienia do Boga w konstytucji powinna stanowić wypadkową ewoluującej doniosłości sfery sacrum dla społeczeństwa danego państwa jako politycznego suwerena.

Słowa kluczowe: Bóg; konstytucja; komparatystyka; kulturowy wymiar prawa; prawo wyznaniowe; prawo konstytucyjne; aksjologia prawa

$$
* * * * *
$$

* Dr hab., prof. UR, Katedra Nauk Historyczno i Teoretycznoprawnych, Instytut Nauk Prawnych, Uniwersytet Rzeszowski, ul. Grunwaldzka 13, 35-068 Rzeszów, e-mail: grzegorzmaron@op.pl. ORCID 0000-0002-3861-9103. 


\section{WSTEP}

Światopogląd społecznej większości, tak religijny, jak i niereligijny, w większym lub mniejszym stopniu, rzutuje na treść stanowionego w danym państwie prawa. Sama jednak treściowa koherentność norm prawnych ze światopoglądem (systemem wartości, ideologią) obywateli i/lub politycznych decydentów nie czyni zadość w pełni ich oczekiwaniom. Pojawia się potrzeba, aby w prawie, a zwłaszcza w konstytucji jako akcie naczelnym dla każdego porządku prawnego, wprost zidentyfikować ten światopogląd (system wartości, ideologię) lub jego ostateczne źródło, którym od wieków dla wielu pokoleń narodów okazywał się być Bóg.

Zamierzeniem badawczym opracowania jest dokonanie komparatystycznej analizy i syntezy bezpośrednich odniesień do Boga w konstytucjach współczesnych państw. Tytułowa problematyka dotychczas była podejmowana w rodzimej jurysprudencji jedynie w wymiarze fragmentarycznym. Poszczególni Autorzy swoje rozważania ograniczali do wybranych państw lub państw określonego obszaru geograficznego. Zwykle mieli też na uwadze jeden typ odniesień do Boga, a mianowicie invocatio lub nominatio Dei w preambułach konstytucji. Ponadto omawianie niniejszego zagadnienia jako części szerszego tematu postanowień konstytucji regulujących kwestie konfesyjne, wymuszało ograniczenie się do zarysowania ogólnych prawidłowości obrazowanych przy pomocy kilku czy kilkunastu przykładów ${ }^{1}$.

Przedkładane opracowanie ma mieć po pierwsze, postać kompleksową w tym sensie, że traktuje o odwołaniach do Boga w konstytucjach wszystkich państw świata, a nie tych egzemplifikacyjnie dobranych. Po drugie, skoncentrowanie się wyłącznie na przypadkach eksplikatywnego nadmieniania Boga w ustawach zasadniczych, a nie na całości materii religijnej normowanej w konstytucjach, pozwoli obrany temat potraktować z należytą - pod kątem analitycznym - wnikliwością, choć wciąż ograniczaną ramami objętościowymi opracowania.

1 Zob. Bała 2011; Bała 2010; Bar 2004; Grześkowiak 1996; Krukowski 1996. 


\section{ZAŁOŻENIA KONCEPTUALNE I METODOLOGICZNE}

Na potrzeby opracowania do tytułowej kategorii „konstytucji” zaliczono obok konstytucji formalnych, czyli mających postać pojedynczego aktu normatywnego o najwyższej mocy prawnej, także - pomimo pewnych wahań - nieliczne konstytucje materialne, czasami niepoprawnie nazywane „niepisanymi”. Konstytucje materialne to zbiór kilku czy kilkunastu aktów, niekiedy znacznie oddzielonych od siebie chronologicznie, regulujących materię konstytucyjną w danym państwie ${ }^{2}$. W przypadku konstytucji materialnej kwestią nie zawsze oczywistą jest katalog aktów normatywnych czy także innych aktów prawnych składających się na nią. Ponadto sporne może pozostawać to, czy konkretne postanowienie jednego z takich aktów wydanych dziesiątki lat - czy nawet wieki temu - wciąż zachowuje moc obowiązującą. Pomimo tych zastrzeżeń, za uwzględnieniem w zakresie badań aktów konstytucyjnych Nowej Zelandii, San Marino, Szwecji czy Wielkiej Brytanii - zawierających odniesienia do Boga - przemawia troska o całościowość analizy obranej tematyki.

Z kolei terminem ,państwa współczesne” objęto 193 państwa członkowskie Organizacji Narodów Zjednoczonych oraz dwa podmioty prawa międzynarodowego mające status obserwatora przy ONZ, czyli Palestynę i Stolicę Apostolską (Państwo Watykańskie). Pominięto natomiast kilkanaście państw oficjalnie nieuznawanych na arenie międzynarodowej.

Artykuł dotyczy odniesień do Boga, a nie ogólnie do sacrum czy duchowości. Z tytułowym zagadnieniem wiąże się, lecz się w nim nie zawiera, odniesienie do Buddy w konstytucji Bhutanu³ . Budda nie był bóstwem, a sam buddyzm zalicza się do religii nieteistycznych. Podobnie odwołaniem do Boga nie jest odwołanie do duchów przodków (manes), obecne w ustawie zasadniczej Beninu ${ }^{4}$, jakkolwiek jest to odwołanie do sfery

2 Do państw posiadających konstytucję w znaczeniu materialnym, a nie formalnym zalicza się także Izrael (w ustawie zasadniczej brak odniesień wprost do Boga) oraz - choć to już bardziej sporne - Kanadę i Arabię Saudyjską (ustawy zasadnicze zawierają odniesienia do Boga).

Bhutan (P). Ze względów edytorskich w przypisach poszczególne konstytucje oznaczam, podając nazwę państwa, a obok w nawiasie wskazuję właściwy artykuł lub literę „P” symbolizującą preambułę ustawy zasadniczej.

4 Benin (art. 53). 
transcendentalnej. W tematyce opracowania nie mieści się także metaforyczne użycie terminu „Bóg” w konstytucji Korei Północnej, polegające na przywołaniu motta Kim Ir Sena i Kim Dzong Ila „Naród moim Bogiem”. W badaniach pominięto także pośrednie i dorozumiane odniesienie do Boga na gruncie Konstytucji Republiki Francuskiej. Pośredni charakter tego odniesienia przejawia się w tym, że jest ono zamieszczone nie w tekście ustawy zasadniczej, lecz w Deklaracji Praw Człowieka i Obywatela z 1789 r., do której konstytucja z 1958 r. odsyła ${ }^{6}$. Z kolei dorozumiany charakter tego odniesienia polega na tym, że Deklaracja expressis verbis stanowi nie o Bogu, lecz „Istocie Najwyższej” będącej filozoficzno-ideologiczną projekcją Boga z okresu Rewolucji Francuskiej.

$\mathrm{W}$ badaniach $\mathrm{w}$ większości wykorzystano anglojęzyczne teksty konstytucji wszystkich państw świata udostępnione na portalu Constitute Project ${ }^{7}$ oraz polskie tłumaczenia kilkudziesięciu ustaw zasadniczych ${ }^{8}$.

W relatywnie nielicznych opracowaniach obcojęzycznych podejmujących tytułową problematykę niekiedy badaniu poddaje się także implikatywne odwołania do Boga, czyli nominalnie mające postać odniesień do religii lub kościołów ${ }^{10}$. Odniesienia obu typów wydają się być jednak na tyle inne, że nie należy ich ze sobą łączyć, czy sugerować ich pojęciową lub funkcjonalną tożsamość.

Odniesienia do Boga w porządku prawnym poszczególnych państw nie wyczerpują się w postanowieniach ustaw zasadniczych. W większym lub mniejszym stopniu odwołania do Boga czy po prostu nadmienienie tego pojęcia występuje także w pozakonstytucyjnych aktach normatywnych oraz aktach stosowania prawa ${ }^{11}$.

5 Socjalistyczna Konstytucja Koreańskiej Republiki Ludowo-Demokratycznej z dnia 27 grudnia 1972 r. (P), http://www.naenara.com.kp/en/politics/?rule [dostęp: 5.06.2019].

${ }_{6}$ Konstytucja Republiki Francuskiej z dnia 4 października 1958 r. (P). Tłum. Wiesław Skrzydło. 2011. W: Konstytucje państw Unii Europejskiej, red. Wiesław Staśkiewicz, 271-296. Warszawa: Wydawnictwo Sejmowe.

7 https://www.constituteproject.org/ [dostęp: 5.06.2019].

8 Większość z polskich tłumaczeń dostępna jest na portalu Biblioteki Sejmowej: http://biblioteka.sejm.gov.pl/konstytucje_swiata/ [dostęp: 5.06.2019].

9 Zob. np. Henry 2018; Iban 2013; Temperman 2010, 65-91.

$10 \quad$ Neo 2017.

11 Zob. Maroń 2014. 
Poniżej przedstawiono rezultaty studium konstytucji współczesnych państw pod kątem obecności w nich odniesień do Boga. Tytułowa problematyka została poddana komparatystycznej aproksymacji, syntezie i ocenie tak w aspekcie kwalitatywnym, jak i kwantytatywnym.

\section{ILOŚCIOWO-JAKOŚCIOWA CHARAKTERYSTYKA ODNIESIEŃ DO BOGA W KONSTYTUCJACH}

\subsection{SKALA PRZYPADKÓW INVOCATIO I NOMINATIO DEI W KONSTYTUCJACH}

Odniesienia do Boga rozpoznano w konstytucjach 124 państw świata, co stanowi blisko 2/3 wszystkich państw globu. Ze względu na usytuowanie w strukturze konstytucji odwołania do Boga najczęściej zamieszczane są w preambule $(85 \mathrm{x})$. Niemal równie często odniesienia tego typu występują w przepisach ustawy zasadniczej podających rotę przysięgi osób sprawujących funkcje publiczne, zwykle głowy państwa, członków rządu, parlamentarzystów czy sędziów (83x). W konstytucjach 23 państw odwołania do Boga pojawiają się także w innych, tematycznie zróżnicowanych, postanowieniach tego aktu.

Nie istnieje konieczny związek pomiędzy statusem danego państwa jako państwa wyznaniowego ${ }^{12}$ a obecnością odwołania do Boga w konstytucji tego państwa. Jedynym z pięciu państw, w których uznaje się za oficjalną religię katolicyzm, w preambule konstytucji którego występuje odwołanie do Boga, jest Kostaryka. W konstytucjach pozostałych formalnie katolickich państw odniesienia takie się w ogóle nie pojawią ${ }^{13}$ lub mają charakter drugorzędny, w tym sensie, iż nie wyrażają afirmatywnego stosunku do Boga, np. fakultatywne „tak mi dopomóż Bóg” w rocie przysięgi $^{14}$, sformułowanie ,z łaski Boga" w odniesieniu do panującego - w momencie przyjęcia aktu - monarchy ${ }^{15}$ czy wzmiankowanie Boga w dacie

12 O nieostrości terminu ,państwo wyznaniowe” zob. Borecki 2017.

13 Konstytucja Księstwa Monako z dnia 17 grudnia 1962 r. Tłum. Agnieszka Wojtyczek-Bonnand, Krzysztof Wojtyczek. 2012. Warszawa: Wydawnictwo Sejmowe.

14 Malta (załącznik nr 2 i 3 ).

15 Lichtenstein (P); Wielka Brytania (Wielka Karta Wolności z 1215 i 1297 r.). 
ustanowienia aktu ${ }^{16}$. Podobnie przedstawia się sytuacja w konstytucjach państw formalnie luterańskich, które nie zawierają odwołań do Boga ${ }^{17}$ lub posługują się odniesieniami niekomunikującymi wyraźnie afirmacji Boga ${ }^{18}$. Zależność pomiędzy typem państwa wyznaniowego a odwołaniami do Boga w tekście ustawy zasadniczej tego państwa występuje natomiast w odniesieniu do państw islamskich. Regułą jest, że ich konstytucje zawierają odniesienia do Boga $\mathrm{w}$ ramach preambuły $\mathrm{i} /$ lub roty przysięgi bądź jeszcze innego postanowienia. Spośród państw islamskich wyróżnia się Arabia Saudyjska, gdzie w art. 1 ustawy zasadniczej stwierdzono, że konstytucją państwa jest „Księga Boga i Sunna Jego Proroka”.

Najczęściej odwołania do Boga pojawiają się w konstytucjach państw obu Ameryk (31 z ogółu 35 państw) oraz obszaru Oceanii (13 z ogółu 14 państw) $)^{19}$. Odniesienia do Boga zawierają konstytucje ponad 2/3 państw afrykańskich (37 z ogółu 54), ponad połowy państw azjatyckich (26 z ogółu 47) oraz ponad 2/5 państw europejskich (19 z ogółu 44) ${ }^{20}$.

16 Państwo Watykańskie.

17 Konstytucja Republiki Finlandii z dnia 11 czerwca 1999 r. Tłum. Joachim Osiński. 2011. W: Konstytucje państw Unii Europejskiej. Warszawa: Wydawnictwo Sejmowe; Konstytucja Republiki Islandii z dnia 17 czerwca 1944 r. Tłum. Stanisław Sagan. 2006. Rzeszów: Wydawnictwo Uniwersytetu Rzeszowskiego.

18 Dania (art. 67), Norwegia (art. 9), Szwecja (Akt o sukcesji z 1810 r. - preambuła oraz data ustanowienia aktu).

19 Wśród państw amerykańskich odniesień do Boga nie zawierają konstytucje Kuby, Meksyku, Urugwaju i Stanów Zjednoczonych, z kolei wśród państw obszaru Oceanii odwołanie do Boga nie występuje jedynie w konstytucji Mikronezji. Brak nadmieniania Boga w konstytucji USA z 1787 r. może dziwić, zważywszy na obecność odniesień do Boga czy boskości w Deklaracji Niepodległości z 1776 r. i konstytucjach wszystkich 50 stanów. Aleksandra Sandstrom. 2017. God or the divine is referenced in every state constitution, https:// www.pewresearch.org/fact-tank/2017/08/17/god-or-the-divine-is-referenced-in-every-state-constitution/ [dostęp: 5.06.2019].

20 W przypadku państw, których terytorium leży na dwóch kontynentach, przy ich klasyfikowaniu decydowało to, gdzie zlokalizowana jest większa część powierzchni kraju. Z tego powodu Egipt zaliczono do krajów afrykańskich, a Turcję i Kazachstan do państw azjatyckich. Jedyny wyjątek uczyniono wobec Rosji, traktując ją za państwo europejskie, a nie azjatyckie z racji tego, że większość jej obywateli zamieszkuje część europejską kraju. Jeśliby państwa europejskie rozumieć bardziej w kategoriach politycznych, a nie tyle geograficznych, to wówczas odsetek państw, których konstytucje obejmują jakiekolwiek invocatio czy nominatio Dei również wyniósłby około 43\% (21 z ogółu 49 państw). W sensie 


\subsection{OKREŚLENIE BOGA W KONSTYTUCJACH}

Wyraz „Bóg” bywa zamiennie stosowany w konstytucjach z innymi terminami, w pewien sposób konkretyzującymi pojmowanie Boga czy wprost identyfikującymi go z założeniami określonych religii. W ustawach zasadniczych trzech państw chrześcijańskich ${ }^{21}$ Boga określono zgodnie z dogmatem monoteistycznego trynitaryzmu, tj. „Święta, Niepodzielna i Współistotna Trójca”22, „Najświętsza Trójca”23 czy „Bóg Ojciec, Syn, Duch Święty"24. O Duchu Świętym wspomina też akt konstytucyjny San Marino $^{25}$. Przyjęcie chrześcijańskiego pojmowania Boga suponuje także określenie go mianem „Ojca”"26 czy nawiązanie do jego „Ojcostwa”27. Bezpośrednie odniesienia do Jezusa Chrystusa - w chrześcijaństwie postrzeganego za prawdziwego Boga i człowieka - pojawiają się w konstytucjach czterech państw, przy czym w dwóch z nich jedynie we fragmentach tekstu określających datę przyjęcia ustawy zasadniczej: ,,w roku Naszego Pana i Zbawiciela Jezusa Chrystusa”28, „w Uroczystość Chrystusa Króla Wszechświata”29. Wymowny jest początek zwrotu „Boski Pan, Jezus Chrystus" z preambuły konstytucji Irlandii wyrażający przekonanie właśnie o boskości Jezusa Chrystusa. Konstytucja Grecji mówi z kolei o „Prawosławnym Kościele Grecji uznającym naszego Pana Jezusa Chrystusa za swoją głowę"30. W konstytucjach kilku państw chrześcijańskich

politycznym za państwa europejskie można uznać 47 państw członkowskich Rady Europy oraz Białoruś i Watykan.

21 W dalszej części artykułu określenie ,państwa chrześcijańskie” i ,państwa islamskie/muzułmańskie" powiązano z demografią wyznaniową jego mieszkańców, a nie z formą ustrojową.

22 Grecja (P oraz art. 23.2, art. 59.1).

23 Irlandia (P).

24 Samoa (cz. I.3).

25 San Marino (art. 13 i 14 Statutu).

26 Kiribati (P).

27 Grenada (P).

28 Szwecja (Akt o sukcesji).

29 Państwo Watykańskie (data).

30 Grecja (art. 3). 
i muzułmańskich Boga nazwano „Stwórcą"31 lub „Panem”32. Tak jak powyżej nadmienione określenie Jezusa Chrystusa mianem „Zbawiciela” w konstytucji Szwecji ma charakter niepowtarzalny, tak też osobliwym na gruncie czynionej analizy komparatystycznej jest nazwanie Boga „najlepszym Protektorem i Obrońcą" w konstytucji Zjednoczonych Emiratów Arabskich $^{33}$.

Odwołania do Boga w konstytucjach państw współczesnych niemal wyłącznie są odniesieniami monoteistycznymi. Wyjątek stanowi konstytucja Bhutanu, w której mowa o „strzegących bóstwach”34. Z kolei w konstytucji Boliwii obok przywołania Boga pojawia się nawiązanie do inkaskiej bogini ziemi, Pachamamy ${ }^{35}$.

Często w konstytucjach ustrojodawcy określają przymioty Boga wskazujące na jego rozumienie. Najpopularniejszą cechą przypisywaną Bogu jest wszechmoc. Odniesienie do Boga „wszechmogącego” pojawia się w konstytucjach 52 państw $^{36}$. W ustawach zasadniczych państw islam-

31 Bangladesz (P), Belize (P), Dominika (P), Grenada (P), Madagaskar (P), Trynidad i Tobago (P).

32 Brunei (P), Grecja (art. 3), Iran (art. 11), Irlandia (P), Nauru (P), Nowa Zelandia (Patent Królewski ustanawiający urząd Gubernatora Generalnego Nowej Zelandii z 1983 r., Traktat z Waitangi z 1840 r.), Szwecja (Akt o sukcesji), Tuvalu (P).

33 ZEA $(\mathrm{P})$.

34 Bhutan $(\mathrm{P})$.

35 Boliwia $(\mathrm{P})$.

36 Afganistan (P, art. 63, art. 74, art. 119), Algieria (art. 90, art. 183), Australia (P), Bahrajn (art. 33, art. 78), Brunei (załącznik nr 1), Chile (P), Dżibuti (P), Egipt (art. 104, art. 144, art. 165), Filipiny (P), Gambia (P), Ghana (P, załącznik nr 2), Indonezja (P), Irak (art. 50), Iran (art. 2.1), Irlandia (art. 12.8, art. 31.4, art. 34.5.1, art. 44.1), Jemen (art. 160), Jordania (art. 43, art. 61, art. 80), Katar (art. 10, art. 74, art. 92, art. 119), Kenia (P), Kiribati (P), Kuwejt (art. 60, art. 91), Lesotho (załącznik nr 1), Liban (art. 50), Libia (art. 19), Malediwy (załącznik nr 1), Mauretania (P), Nauru (P, załącznik nr 1,3 i 4), Norwegia (art. 9), Oman (art. 7, art. 50, art. 58'20), Pakistan (P), Palau (P), Palestyna (art. 35, art. 49), Peru (P), Saint Kitts i Navis (P), Saint Lucia (P), Samoa (P, załącznik nr 3), Seszele (P), Somalia (art. 1.2), Suazi (P), Sudan (P, art. 56, art. 71, art. 89), Sudan Południowy (P, art. 65, art. 99, art. 107), Surinam (P), Syria (art. 7), Szwajcaria (P), Tonga (cz. II.34), Tunezja (art. 58, art. 76, art. 89), Tuvalu (P), Uganda (załącznik nr 4), Zambia (P), Zimbabwe (P), Zjednoczone Emiraty Arabskie (P, art. 52, art. 57, art. 73), Zjednoczone Królestwo (Bill of Rights z 1689 r.; Ustawa o następstwie tronu z 1700 r.). 
skich Boga określa się także jako „miłosiernego"/,najmiłosierniejszego"37, „współczującego” czy „łaskawego”/,najłaskawszego”38, „wielkiego”/ „najwyższego"39. W statucie San Marino posłużono się zwrotem „Bogu Najlepszemu i Najwyższemu"40.

Zwraca uwagę, iż w konstytucjach państw chrześcijańskich zasadniczo nie wymienia się miłości czy miłosierdzia jako właściwości Boga, pomimo tego, że doktryna chrześcijańska głosi, iż Bóg jest miłością ${ }^{41}$. Do wyjątków należy ustawa zasadnicza Samoa, w której Boga określono jako „Wiecznie Kochającego"42. W brytyjskim Bill of Rights z 1689 r. jest z kolei mowa o „cudownej opatrzności i miłosiernej dobroci” Boga wobec brytyjskiego narodu. W konstytucjach pojedynczych państw podawane są także inne cechy Boga jak: wszechobecnośćc ${ }^{43}$, wszechwiecznośćc ${ }^{44}$, wszechwiedza ${ }^{45}$, wywyższenie $^{46}$. Oryginalnym sformułowaniem posłużono się w konstytucji Afganistanu, gdzie mowa o Bogu ,miłującym i podtrzymującym świat" 47 .

W konstytucjach kilku państw islamskich zwrotem ,jedyny Bóg”48 podkreślono przekonanie, że tylko Allah jest prawdziwym Bogiem. Konstytucja Indonezji i Pakistanu stanowi o ,wierze w jednego i jedynego

37 Afganistan (P, art. 63, art. 74, art. 119) ), Algieria (art. 90), Arabia Saudyjska (P), Bangladesz (P), Brunei (P), Egipt (P), Irak (P), Iran (P, art. 67, art. 121), Jemen (Konstytucyjna Deklaracja o podstawach sprawowania władzy w okresie przejściowym w Jemenie), Komory (art. 13), Kuwejt (P), Libia (P), Pakistan (załącznik do art. 2A), Palestyna (P), Tunezja $(\mathrm{P})$.

38 Afganistan (P, art. 63, art. 74, art. 119), Algieria (art. 90), Arabia Saudyjska (P), Bangladesz (P), Brunei (P), Egipt (P), Iran (P, art. 67, art. 121), Irak (P), Jemen (Konstytucyjna Deklaracja o podstawach sprawowania władzy w okresie przejściowym w Jemenie), Komory (art. 13), Kuwejt (P), Libia (P), Pakistan (załącznik do art. 2A), Palestyna (P), Tunezja (P).

39 Afganistan (art. 19 i 20), Gambia (P); Iran (P, art. 18), Zjednoczone Emiraty Arabskie $(\mathrm{P})$.

40 San Marino (art. XIV).

41 Deus caritas est (zob. $1 \mathrm{~J}$ 4:8).

42 Samoa $(\mathrm{P})$.

43 Samoa $(\mathrm{P})$.

44 Nauru (P), Tuvalu (P).

45 Norwegia (art. 9).

46 Iran (art. 67, art. 121).

47 Afganistan (P).

48 Indonezja (P), Iran (art. 2.1), Mauretania (art. 29), Pakistan (załącznik nr 3). 
Boga”. Sformułowanie to wyraża zarówno monoteizm, jak i przeświadczenie o fałszywości innych niż Allah wyobrażeń Boga. To samo przekonanie komunikuje muzułmańskie wyznanie wiary (szahada) - „Nie ma Boga prócz Allaha, a Mahomet jest jego prorokiem” - wyartykułowane wprost w konstytucjach Arabii Saudyjskiej i Afganistanu ${ }^{49}$.

\subsection{TEMATYCZNA I FUNKCJONALNA RÓŻNORODNOŚĆ ODNIESIEŃ DO BOGA}

Regułą jest, że odwołania do Boga obecne w tekstach konstytucji nie licząc tych przewidzianych w rotach przysięgi - mają charakter afirmatywny, a nie tyle sprawozdawczy. Jedynym wyjątkiem są konstytucje Nikaragui i Polski. W ustawie zasadniczej Nikaragui ustrojodawca mówi o „chrześcijanach, którzy inspirowani wiarą w Boga przyłączyli się i oddali walce o wyzwolenie uciskanych" ${ }^{50}$. Z kolei w rodzimej konstytucji nawiązanie do Boga pojawia się w ramach charakterystyki Narodu grupującego obywateli Rzeczypospolitej, wśród których znajdują się ci ,wierzący w Boga" ${ }^{51}$.

Klasycznym invocatio Dei polegającym na stwierdzeniu, że konstytucję ustanowiono „w imię Boga” rozpoczynają się ustawy zasadnicze 17 państw, w większości muzułmańskich ${ }^{52}$. Sformułowanie to sugeruje swoiste pełnomocnictwo udzielone przez Boga ustrojodawcy do ustanowienia konstytucji. Funkcjonalnie podobnego charakteru jest początek wstępu do konstytucji Zjednoczonych Emiratów Arabskich: „Ogłaszając Najwyższemu i Wszechmogącemu Allahowi" ${ }^{33}$. W kilku konstytucjach zawarto wyrażenie ,przywołując imię Boga" ${ }^{54}$.

Odwołania do Boga w preambułach konstytucji przybierają także wiele innych leksykalnych formuł, bardziej lub mniej rozbudowanych, o róż-

49 Arabia Saudyjska (art. 3) i Afganistan (art. 19).

50 Nikaragua $(\mathrm{P})$.

51 Polska (P).

52 Arabia Saudyjska (P), Afganistan (P), Bahrajn (P), Brunei (P), Dżibuti (P), Egipt (P), Gambia (P), Ghana (P), Grecja (P), Irak (P), Irlandia (P), Jemen (Konstytucyjna Deklaracja o podstawach sprawowania władzy w okresie przejściowym w Jemenie z 2015 r.), Kuwejt (P), Libia (P), Pakistan (załącznik do art. 2A), Samoa (P), Szwajcaria (P), Tunezja (P).

53 ZEA (P).

54 Chile (P), Dominikana (P), Ekwador (P), Gwatemala (P), Kostaryka (P). 
nych motywach. Do najbardziej językowo ogólnych należą wyrażenia:

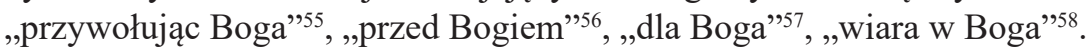
Wątek ochrony ze strony Boga artykułują słowa: „pod ochroną Boga" 59 , „przywołując ochrony Boga" 60 ; „Niech Bóg chroni nasz Naród/Lud”61, „oddając się pod ochronę Boga" "2, „pokornie oddajemy się pod ochronę Jego dobrej opatrzności”'63. O pożądanej pomocy i przewodnictwie ze strony Boga dla państwa i narodu stanowią słowa: „z pomocą Boga” ${ }^{44}$, „przywołując pomocy Boga" ${ }^{\prime 65}$, „błagając o przewodnictwo i wsparcie Wszechmogącego Boga" ${ }^{{ }^{6}}$, „pod przewodnictwem Boga" ${ }^{67}$, „opierając się na Jego Boskim przewodnictwie" ${ }^{68}$, „pod prowadzącą ręką Boga" ${ }^{69}$. Pokrewnego charakteru jest przywołanie Bożej pomyślności czy przychylności dla państwa i jego mieszkańców pod postacią błogosławieństwa Boga ${ }^{70}$.

W kilku konstytucjach dano wyraz zawierzeniu się Bogu, co komunikują słowa ,pokładając ufność (w Bogu)" "11. Analogiczną wymowę mają słowa: „W rękach (Boga Wszechmogącego) leży nasza przyszłość”’², „wchodzimy w przyszłość w pełni polegając na naszych własnych wysiłkach i boskim przewodnictwie Wszechmogącego Boga"73, „opierając się

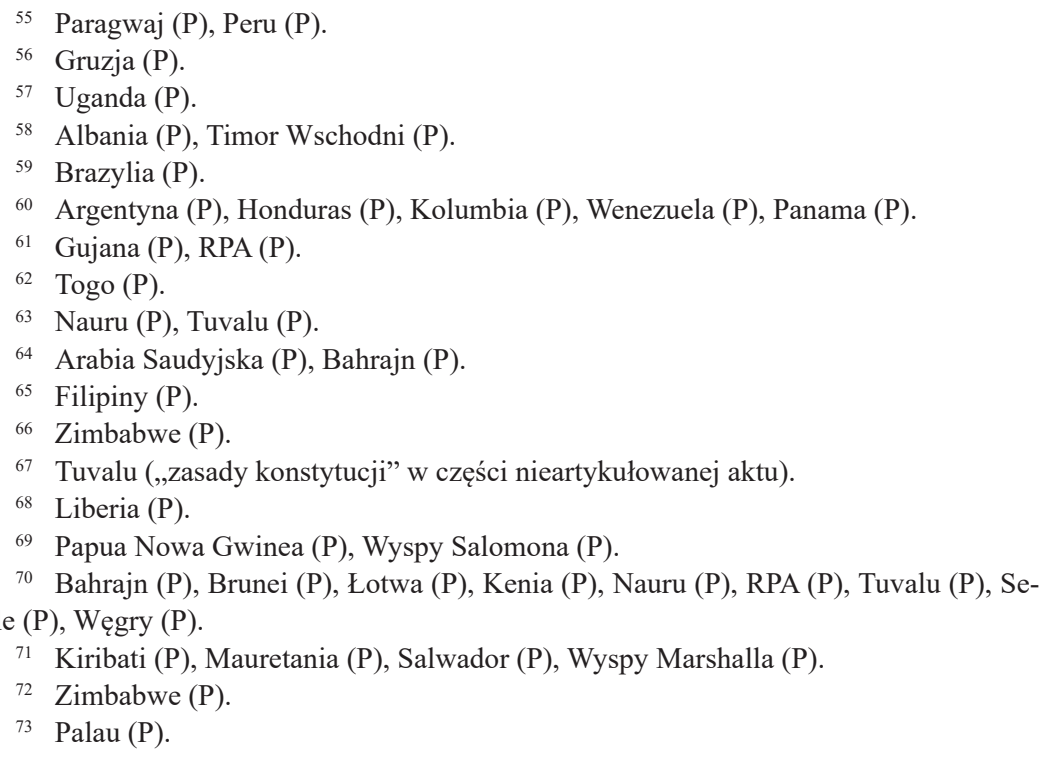


na Jego Boskim przewodnictwie dla naszego przetrwania jako Narodu"74, czy ,jak Bóg pozwoli"75.

W siedmiu konstytucjach wyrażono przekonanie o odpowiedzialności ustrojodawcy, funkcjonariuszy publicznych czy generalnie obywateli przed Bogiem. O ile konstytucja Iranu stanowi o odpowiedzialności człowieka wyłącznie przed Bogiem ${ }^{76}$, o tyle w konstytucjach pozostałych państw wskazano także inne podmioty czy instancje, przed którymi ponosi się odpowiedzialność, tj. „ludzi"77, „naród, Afrykę i świat”78, „historię"79, „własne sumienie" ${ }^{\circ 0}$, „poprzednie, obecne i przyszłe pokolenia”81.

W konstytucjach około 30 państw, będących niegdyś pod panowaniem Imperium Brytyjskiego, sformułowano zasadę zwierzchnictwa Boga. W połowie przypadków została ona ujęta expressis verbis. Zwykle w konstytucjach mowa jest ogólnie o uznaniu zwierzchnictwa Boga ${ }^{82}$, rzadziej o „zwierzchnictwie nad (całym) wszechświatem"83. Niewyrażoną wprost ideę zwierzchnictwa Boga można natomiast wywodzić z kilku rodzajów sformułowań. Wskazuje na nią określenie Boga mianem „Najwyższego"84, „Na wysokościach”85, „Panem Wszechświata”86 czy określenie narodu jako tego, „nad którym” znajduje się Bóg ${ }^{87}$. Podobnie fragmenty stanowiące

74 Liberia (P).

75 Bahrajn (P). Słowa te występują także w rocie przysięgi przewidzianej w konstytucji Bangladeszu (załącznik nr 5).

${ }^{76}$ Iran (art. 2.6). Art. 122 stanowi jednak, że prezydent kraju odpowiada przed ,narodem, przywódcą i Islamskim Zgromadzeniem Konsultatywnym”.

77 Niemcy (P), Pakistan (załącznik do art. 2A).

78 Demokratyczna Republika Kongo (P).

79 Gwinea Równikowa (P), Gabon (P).

${ }^{80}$ Polska (P), Ukraina (P).

81 Ukraina (P).

82 Antigua i Barbuda (P), Bahamy (P), Barbados (P), Belize (P), Dominika (P), Grenada (P), Iran (art. 2.1, art. 56), Pakistan (P), Samoa (P), Saint Lucia (P), Saint Vincent i Grenadyny (P), Trynidad i Tobago (P), Kanada (P części pierwszej Aktu konstytucyjnego z 1982 r., czyli Kanadyjskiej Karty Praw i Wolności), Kenia (P), Zambia (P), Zimbabwe (P).

83 Samoa (P), Pakistan (załącznik do art. 2A).

84 Liban (art.9), Zjednoczone Emiraty Arabskie (P).

85 Bahrajn $(\mathrm{P})$.

86 Brunei (P).

87 Bahamy (P), Irlandia (art. 6 ust. 1), Nigeria (P), Seszele (P), Zjednoczone Królestwo (Bill of Rights z 1689 r., Ustawa o następstwie tronu z 1700 r.). 
o ,pokornym poddaniu się, Bogu ${ }^{88}$, „uznaniu obowiązków” wobec Boga ${ }^{89}$, „sprawowaniu władzy w granicach Bożych przykazań”,90, „poleganiu na Jego boskiej woli”,91, „uznaniu Bożych praw nad nami"92 czy zastrzeżenie, że wszelka władza jest powierzona ludowi, ale w drugiej kolejności ,po Wszechmogącym Allahu"93 implikuje zwierzchnictwo Boga.

W konstytucjach kilkunastu państw pojawia się motyw Boga jako dawcy, stworzyciela bądź źródła tego, co dla ludzi cenne i konieczne. Najogólniej Boga w tym kontekście określono w konstytucjach Nauru i Tuvalu, tj. jako dawcę ,wszelkich rzeczy"94. Boga przedstawia się w ustawach zasadniczych także jako stwórcę „ludzi”" czy „Ziemi”96, dawcę bądź źródło „,̇̇ycia”97, „wolności”,98, „władzy” politycznej ${ }^{99}$, „sumienia” ${ }^{100}$, „sprawiedliwości”"101, „tożsamości”"102, „rozumu”103, „prawdy”"104, „piękna”105 i ,godności”"106.

Najczęściej w Bogu upatruje się dawcy uniwersalnych praw człowieka, określanych niekiedy jako praw „równych”, „niezbywalnych”, „nieodłącznych”, ewentualnie od Boga wywodzi się ludzką godność, w której

88 Suazi (P).

89 Bahrajn (P), Irlandia (P).

90 Samoa $(\mathrm{P})$.

91 Afganistan (P).

$92 \operatorname{Irak}(\mathrm{P})$.

93 Somalia (art. 1.2).

94 Nauru (P), Tuvalu (P).

95 Tonga (cz. I.1).

96 Egipt (P).

97 Wyspy Marshalla (P).

98 Tonga (cz. I.1, dosłownie konstytucja stanowi, że jest ,wolą Boga, aby ludzie byli wolni”), Wyspy Marshalla (P).

99 Irlandia (art. 6.1). W preambule do konstytucji stwierdzono, że wszelka władza pochodzi od Trójcy Przenajświętszej, z kolei w art. 6 doprecyzowano, że wszelka władza państwowa, ustawodawcza, wykonawcza i sądownicza, pochodzi od Narodu, nad którym Bóg.

100 Grenada (P).

101 Argentyna (P), Polska (P).

102 Wyspy Marshalla (P).

103 Argentyna (P), Grenada (P).

104 Polska (P).

105 Polska (P).

${ }^{106}$ Libia (art. 7), Saint Lucia (P), Somalia (art. 10). 
prawa te czerpią swoje umocowanie ${ }^{107}$. W konstytucji Tuvalu Boga określono jako dawcę prawa Narodu do pełnego, wolnego i szczęśliwego życia, do moralnego, duchowego, osobistego i materialnego dobrobytu ${ }^{108}$. Z kolei konstytucja Arabii Saudyjskiej stanowi, że Bóg podarował temu państwu zasoby naturalne ${ }^{109}$.

W konstytucjach kilku państw wyrażono Bogu wdzięczność, zwykle za jego konkretny wkład do historii państwa i narodu: ,zamieszkanie jednego z najpiękniejszych krajów na świecie" ${ }^{110}$, ,istnienie jako wolnego, suwerennego i niepodległego państwa”"111, podarowanie ludowi „mądrości i odwagi do określenia swojego przeznaczenia i przyszłości”"112, obdarowanie „mądrością i wolą do osiągnięcia porozumienia pokojowego" "113, „stabilność społeczeństwa” oraz „szczęście i pomyślność narodu” ${ }^{114}$ czy za „przekształcenie” (refundamos) państwa"115. Na opatrznościową rolę Boga w dziejach narodu wskazano także w konstytucji Irlandii, wspominając o Jezusie Chrystusie, jako tym, „który wspomagał naszych ojców przez wieki próby"116 oraz w konstytucji Indonezji, przypisując uzyskanie niepodległości przez to państwo m.in. „łasce Boga Wszechmogącego"117.

W konstytucjach Brunei i Libanu oraz aktach konstytucyjnych San Marino i Wielkiej Brytanii jest mowa - niekiedy nawet w formule wyraźnej powinności - o wychwalaniu Boga ${ }^{118}$. Konstytucje Danii i Tonga określeniem „oddawanie czci Bogu” posługują się w kontekście wolności

${ }^{107}$ Belize (P), Dominika (P), Grenada (P), Saint Lucia (P), Somalia (art. 10), Trynidad i Tobago (P), Wyspy Marshalla (P).

108 Tuvalu (zasada konstytucji nr 2).

109 Arabia Saudyjska (art. 14).

110 Seszele (P).

111 Liberia (P).

112 Południowy Sudan (P).

113 Sudan (P).

114 Tuvalu (zasada konstytucji nr 3).

115 Boliwia (P).

116 Irlandia (P).

117 Indonezja (P).

118 Afganistan (P), Brunei (P), Irlandia (art. 44.1.), Liban (art. 9), San Marino (art. 14, wspomniano pieśń religijną Te Deum Laudamus), Zjednoczone Królestwo Wielkiej Brytanii i Irlandii Północnej (art. 61 Wielkiej Karty Swobód z 1215 r.). 
religijnej jednostki ${ }^{119}$. Statut San Marino zakazuje „bluźnić lub przeklinać” $\mathrm{Bogu}^{120}$ oraz wspomina o modlitwie do Boga ${ }^{121}$. Podobnie w konstytucji Gambii mowa jest o modlitwie wstawienniczej do ,wielkiego Boga Narodów"122.

Konstytucje kilku państw wskazując osobę monarchy panującego w czasie ich ogłaszania, posługują się sformułowaniem „z łaski Boga”"123. W jednym $z$ aktów konstytucyjnych Nowej Zelandii zawarto zawołanie „Boże chroń Królową!”124.

W konstytucjach sześciu państw Boga przedstawiono w kategoriach bytu konstytutywnego dla trwania narodu czy państwa: „Samoa to chrześcijański Naród oparty na Bogu Ojcu, Synu i Duchu Świętym” ${ }^{25}$, „Republika Vanuatu oparta na (...) wierze w Boga”"126, „Naród opiera się na wierze w zwierzchnictwo Boga" 127 , „Naród jest ustanowiony na wierze w Wszechmogącego Boga” ${ }^{28}$, „Naród Trynidadu i Tobago opiera się na zasadach uznających zwierzchnictwo Boga”"129 „,Państwo ma być oparte na wierze w jednego i jedynego Boga" ${ }^{130}$.

O ile w konstytucjach większości państw odwołania do Boga są treściowo bardzo ograniczone, często sprowadzając się do pojedynczego wyrażenia, o tyle w ustawach zasadniczych państw islamskich zwykły przyjmować obszerniejszą postać. Przykładem jest konstytucja Iranu, w której

119 Dania (art. 67), Tonga (cz. I.5).

${ }^{120}$ San Marino (art. 37). Por. Irlandia (art. 44.1 i - sprzed nowelizacji z 2018 r. art. 40.6).

121 San Marino (art. 14, art. 48).

122 Gambia (P).

${ }^{123}$ Liechtenstein (P), Nowa Zelandia (Ustawa o tytułach królewskich z 1974 r.; Patent Królewski ustanawiający urząd Gubernatora Generalnego Nowej Zelandii z 1983 r., załącznik do ustawy o wolności osobistej z 2001 r.), Szwecja (Akt o sukcesji), Tuvalu (art. 48), Zjednoczone Królestwo Wielkiej Brytanii i Irlandii Północnej (Wielka Karta Swobód z 1215 i 1297 r.).

124 Nowa Zelandia (Proklamacja o pieczęci Nowej Zelandii z 1977 r.).

125 Samoa (cz. I.3).

126 Vanuatu (P).

127 Saint Vincent i Grenadyny (P).

${ }_{128}$ Saint Kitts i Nevis (P).

129 Trynidad i Tobago (P).

${ }^{130}$ Indonezja (art. 29). 
termin „Bóg” nadmieniono ponad 20 razy. Szczególnego charakteru jest art. 2 tamtejszej ustawy zasadniczej, w którym odwołania do Boga wpisują się w charakterystykę islamu jako kluczowego wyznacznika tożsamości państwa ${ }^{131}$.

\subsection{ODNIESIENIA DO BOGA W ROCIE PRZYSIĘGI}

Przysięga to solenne, publiczne, zwykle ustne, wyrażone słowami konkretnej roty i w określony sposób zobowiązanie się do należytego sprawowania obejmowanego urzędu ${ }^{132}$. W tekstach przysięgi podanych w konstytucjach aż 83 państw pojawia się odniesienie do Boga. Nie oznacza to, że w pozostałych państwach przysięga funkcjonariuszy publicznych jest całkowicie pozbawiona, choćby fakultatywnych, elementów religijnych. Często rotę przysięgi osób pełniących funkcje publiczne normuje się na poziomie ustawowym, którego analiza nie jest objęta niniejszym artykułem ${ }^{133}$. O ile konstytucje większości państw formułują jedną lub kilka rot przysięgi, o tyle ustawy zasadnicze niektórych państw wymieniają nawet kilkanaście tekstów przysięgi, jak w przypadku Pakistanu (16x), Indii (13x) czy Ghany $(12 x)$.

Najczęstszą formułą przywołania Boga w procedurze zaprzysiężenia są słowa „Tak mi dopomóż Bóg”134 lub pokrewne typu „Tak mi do-

131 Zob. szerzej Nikołajew 2015.

132 Powyższe określenie dotyczy przysięgi składanej przez osoby pełniące funkcje publiczne lub wykonujące zawód zaufania publicznego. Dwiema kolejnymi kategoriami przysięgi, o których zasadniczo konstytucje nie stanowią, są przysięga prawdomówności świadka w postępowaniu sądowym oraz przysięga lojalności osoby naturalizowanej.

133 Maroń 2012, 156-157.

134 Albania (art. 88.3), Antigua i Barbuda (załącznik nr 3), Australia (załącznik), Barbados (załącznik nr 1), Belize (załącznik nr 3), Fidżi (załączniki przysięgi i ślubowania), Filipiny (art. 7.5), Ghana (załącznik nr 2), Grenada (załącznik nr 3), Jamajka (załącznik nr 1), Kenia (załącznik nr 3), Lesotho (załącznik nr 1 i 3), Lichtenstein (art. 54.1, art. 108), Litwa (art. 5 ustawy o trybie wejścia w życie Konstytucji Republiki Litewskiej), Malta (załącznik nr 2 i 3), Malawi (art. 81), Mauritius (załącznik nr 3), Namibia (załączniki nr 1, 2 i 3), Nauru (załączniki nr 1, 3 i 4), Niemcy (art. 56), Nigeria (załącznik nr 7), Nowa Zelandia (art. 6b Patentu Królewskiego ustanawiającego urząd Gubernatora Generalnego Nowej Zelandii z 1983 r.), Papua Nowa Gwinea (cz. I.7), Polska (art. 104, art. 130, art. 151), Rumunia (art. 82.2), Rwanda (art. 102), Saint Kitts i Navis (załącznik nr 4), RPA (załącz- 
pomóż Boże Wszechmogący”135, „Tak mi dopomóż Boże Wszechmogący i Wszechwiedzący”136, „Niech Bóg mnie poprowadzi i wspomoże”137, „Niech Wszechmogący Bóg dopomoże mi i strzeże mnie”"138, „Niech Bóg nam dopomoże"139, „Szukając pomocy u Boga"140. Osobliwa jest formuła zaprzysiężenia funkcjonariuszy publicznych Kostaryki. Osoba odbierająca przysięgę wobec zaprzysięganego wypowiada słowa „Niech Bóg ci dopomoże”, zarazem dodając - jeśliby zaprzysięgany miał się nie podjąć powinności zespolonych z jego urzędem: „Niech On [Bóg] i Państwo pociągną cię do odpowiedzialności"141. Równie oryginalną rotę przewiduje akt konstytucyjny San Marino z 1600 r., w którym pojawia się zwrot ,„przysięgam na Święte Ewangelie Boga” oraz „Ku chwale i czci Boga Najlepszego i Najwyższego" ${ }^{\prime 142}$.

Inne popularne odesłania do Boga $\mathrm{w}$ ramach zaprzysiężenia to zwroty: „przysięgam Bogu”143, przysięgam „przed Bogiem”144, przysięgam „na Boga” (zwykle „wszechmogącego”) ${ }^{145}$, przysięgam „w imię

nik nr 2), Samoa (załącznik nr 3), Seszele (załącznik nr 6), Sierra Leone (załączniki nr 2 i 3 ), Suazi (załącznik nr 2), Sudan Południowy (art. 65, art. 99, art. 107), Tuvalu (załącznik nr 4), Uganda (załącznik nr 4), Wyspy Salomona (załącznik nr 1), Zimbabwe (załącznik nr 3), Zjednoczone Królestwo Wielkiej Brytanii i Irlandii Północnej (Bill of Rights z 1689 r.).

135 Surinam (art. 65, art. 93, art. 114, art. 125).

136 Norwegia (art. 9).

${ }^{137}$ Irlandia (art. 12 ust. 8, art. 34.5.1).

138 Pakistan (załącznik nr 3).

139 Niger (art. 50, art. 74, art. 89, art. 124).

${ }^{140}$ Iran (art. 121).

141 Kostaryka (art. 194).

${ }^{142}$ San Marino (art. 5 i art. 14 Statutu).

${ }^{143}$ Kolumbia (art. 192), Panama (art. 181), Timor Wschodni (art. 77.3).

144 Benin (art. 53), Dominikana (art. 127), Gruzja (art. 71.1), Haiti (art. 135-1 i art. 187), Indonezja (art. 9), Komory (art. 13), Demokratyczna Republika Kongo (art. 74), Kostaryka (art. 194), Mali (art. 37), Niger (art. 50, art. 74, art. 89), Republika Środkowo-Afrykańska (art. 38), Senegal (art. 37), Togo (art. 64), Tonga (cz. II.34 i II.83).

${ }^{145}$ Algieria (art. 90, art. 183), Bahrajn (art. 33, art. 78), Brunei (załącznik nr 1), Egipt (art. 104, art. 144, art. 165), Irak (art. 50), Iran (art. 67, art. 121), Jemen (art. 160), Jordania (art. 43, art. 61, art. 80), Katar (art. 10, art. 74, art. 92, art. 119), Kiribati (załącznik nr 1), Kuwejt (art. 60, art. 91), Liban (art. 50), Libia (art. 19), Nauru (załączniki nr 1, 3 i 4), Oman, (art. 7, art. 50, art. 58’20) Palestyna (art. 35, art. 49), Samoa (załącznik nr 3), Sudan (art. 56, art. 71 i art. 89), Sudan Południowy (art. 65, art. 99, art. 107), Syria (art. 7), Tunezja (art. 58, 
Boga"146, „A Bóg mym świadkiem”147 czy przysięgam „w obecności Boga"148. Jakkolwiek różnice pomiędzy powyższymi sformułowaniami mogą wydawać się jedynie stylistycznej natury, to niemniej jednak pociągają one za sobą także pewne konsekwencje semantyczne. Zwroty „przysięgam Bogu” czy „przysięgam przed Bogiem” wskazują, że to sam Bóg jest adresatem przysięgi, choć niekoniecznie jedynym ${ }^{149}$. Formuła „przysięgam na Boga”, „w imię Boga”, „w obecności Boga”, „A Bóg mym świadkiem" czyni z Boga swoistego gwaranta czy poręczyciela dochowania przysięgi. Z kolei zawołanie „Tak mi dopomóż Bóg” jest prośbą skierowaną do Boga o wsparcie przysięgającego w sprostaniu zaciągniętym zobowiązaniom.

Rota niektórych przysiąg stanowi swoiste credo, jak np. przysięga prezydenta i premiera Pakistanu: „W imię Allaha, najłaskawszego i najmiłosierniejszego. Ja..... uroczyście przysięgam, że jestem muzułmaninem, wierzę w jednego i jedynego Wszechmogącego Allaha, Księgi Allaha, Święty Koran będący ostatnią z nich, proroctwo Mahometa (pokój niech będzie z nim) jako ostatniego z proroków, po którym nie może być żadnego proroka, Dzień Sądu, wszystkie wymogi i nauczania Świętego Koranu i Sunny....[Niech Wszechmogący Allah dopomoże mi i strzeże mnie (Amen) $]^{" 150}$.

art. 76, art. 89), ZEA (art. 52, art. 57, art. 73). Podobnie: „przysięgam po trzykroć na Boga” - dosłownie „Wallahi Wa-Billahi, Watallahi” (Brunei, załącznik nr 1 oraz Malezja, załącznik nr 4) czy przysięgam „na imię Boga” (Afganistan, art. 63).

${ }_{146}$ Afganistan (art. 74, art. 119), Algieria (art. 90), Ghana (załącznik nr 2), Indie (art. 60, art. 159, załącznik nr 3), Iran (art. 67, art. 121), Malediwy (załącznik nr 1), Pakistan (załącznik nr 3), Sierra Leone (załączniki nr 2 i 3), Somalia (art. 96, art. 104), Uganda (załącznik nr 4). Podobnie Grecja: „przysięgam w imię Świętej, Współistotnej i Niepodzielnej Trójcy” (art. 23.2, art. 59.1).

${ }^{147}$ Algieria (art. 90), Irak (art. 50), Palestyna (art. 35, art. 49), Sudan (art. 56, art. 71, art. 89), Sudan Południowy (art. 65, art. 99, art. 107).

148 Irlandia (art. 12.8, art. 31.4, art. 34.5.1), Lesotho (załącznik nr 1), Madagaskar (art. 48), Tonga (cz. II.95).

149 Benin (,przed duchami przodków, Narodem i przed ludem Beninu”), Kolumbia (,i obiecuję Ludowi”, art. 192), Demokratyczna Republika Kongo (,i Narodem”, art. 74), Panama (,i Państwu”, art. 181), Timor Wschodni („Narodowi i na mój własny honor”, art. 77.3).

${ }^{150}$ Pakistan (załącznik nr 3). 
O ile w państwach chrześcijańskich alternatywą wobec religijnej przysięgi często jest pozbawione religijnych odniesień ślubowanie, o tyle w konstytucjach państw islamskich regułą pozostaje obligatoryjna religijna przysięga. Jedynym wyjątkiem jest ustawa zasadnicza Brunei, przewidująca możliwość złożenia zamiast religijnej przysięgi świeckiego oświadczenia $^{151}$.

\subsection{ODNIESIENIA DO BOGA W SYMBOLACH PAŃSTW}

Odniesienia do Boga występują także w oficjalnych symbolach państw, których normatywną postać ustalono w konstytucji. Mottem Dominikany są słowa „Bóg, Państwo, Wolność” ${ }^{52}$. Częściowo podobne słowa „Bóg, Państwo, Król" stanowią motto Maroka ${ }^{153}$. Na godło Dominikany składa się wspomniane powyżej motto oraz wizerunek Biblii otwartej na słowach Ewangelii Jana „poznacie prawdę, a prawda was wyzwoli” (J 8:32) ${ }^{154}$.

Na fladze Afganistanu i Arabii Saudyjskiej znajduje się inskrypcja szahady „Nie ma Boga oprócz Allaha, a Mahomet jest jego prorokiem”155. W skład flagi pierwszego z tych państw oraz Iranu ${ }^{156}$ wchodzi z kolei takbir, czyli słowa „Allahu Akbar” (Bóg jest Wielki).

Rotę hymnu Gujany stanowią słowa „Niech Bóg Cię [Gujano] strzeże"157. W hymnie Kenii pojawia się zawołanie „O Boże wszelkiego stworzenia"158, a z kolei w pieśni narodowej Afganistanu „Allahu Akbar”"159.

Nadmienić jedynie można, że szereg innych odwołań do Boga w symbolach poszczególnych państw ma umocowania pozakonstytucyjne, np. motta kilkunastu państw (Brunei, Dominika, Fidżi, Filipiny, Granada, Irak, Jordania, Monako, Nauru, Salwador, Samoa, Tonga, Tuvalu, Uganda, USA, Vanuatu) czy flaga z takbir (Irak).

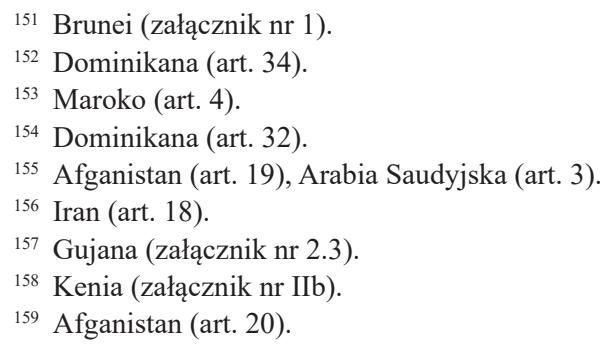




\section{ODNIESIENIA DO BOGA W USTAWACH ZASADNICZYCH NA TLE WSPÓŁCZESNEGO KONSTYTUCJONALIZMU}

Nie istnieje jednolita tendencja w zakresie dokonywania zmian we współczesnych konstytucjach pod kątem zamieszczania w nich lub usuwania odniesień do Boga. Podać można przykłady w obu kierunkach. Wprowadzona do konstytucji Łotwy w 2014 r. preambuła zawiera zawołanie „Boże błogosław Łotwie”. Podobną prośbę skierowaną do Boga zamieszczono w konstytucji Węgier z 2011 r. Odniesienia do Boga zawarto po 1989 r. w kilku innych konstytucjach państw byłego „bloku wschodniego" ${ }^{160}$. Z drugiej strony można wskazać kazus Fidżi. Obecnie obowiązująca konstytucja z 2013 r. fakultatywne odwołanie do Boga przewiduje jedynie w kontekście przysięgi. Preambuła poprzedniej ustawy zasadniczej z 1997 r. zawierała takie sformułowania jak: ,poszukując błogosławieństwa Boga, który od zawsze czuwa nad tymi wyspami”, „mając Boga za naszego świadka", a wśród kluczowych wydarzeń historycznych dla Narodu Fidżi wymieniała ,przejście rdzennych mieszkańców tych wysp z pogaństwa na chrześcijaństwo mocą imienia Jezusa Chrystusa”. W Irlandii od kilkunastu lat nasilają się postulaty usunięcia odniesień do Boga z ustawy zasadniczej ${ }^{161}$.

W przypadku niektórych państw, zwłaszcza tych, których ustawy zasadnicze pochodzą sprzed dziesiątków lat, konstytucyjne odwołania do Boga stały się obecnie formą jedynie tzw. ceremonialnego deizmu ${ }^{162}$. Stanowią one bardziej świadectwo historii danego państwa niż dają wyraz współczesnemu pojmowaniu kwestii źródeł legitymizacji władzy i aksjologii oraz stosunku do transcendencji. Z drugiej jednak strony, fakt iż w nowo stanowionych konstytucjach zachowuje się odniesienia do Boga występujące $\mathrm{w}$ poprzednich ustawach zasadniczych, a nawet wprowadza w sytuacji ich wcześniejszego braku, dowodzi, że invocatio i nominatio

160 Albania, Gruzja, Litwa, Polska, Rumunia, Ukraina. Zob. Schmid 2004, 23.

${ }^{161}$ Patsy McGarry, HAI Urge: Remove 'God' From Constitution, https://www. humanism.ie/2016/10/hai-urge-remove-god-from-constitution/ [dostęp: 5.06.2019]; Conn Corrigan, New campaign to remove God from Irish constitution, https://www.irishcentral. com/news/new-campaign-to-remove-god-from-irish-constitution-44312787-237357451 [dostęp: 5.06.2019].

162 Zob. Maroń 2017. 
Dei nie wolno postrzegać za relikt minionych czasów o jedynie ornamentacyjnej doniosłości.

\section{PODSUMOWANIE}

Konstytucyjne odniesienia do Boga przejawiają podobieństwo do konstrukcji generalnych klauzul odsyłających. Postanowienia ustaw zasadniczych odsyłają do Boga jako bytu pozaprawnego, w sensie jego pozasystemowego zaszeregowania. Jednocześnie przez odesłanie ów byt nabywa prawną relewantność na gruncie danego porządku prawnego. Następuje wówczas nie klasyczna prawna pozytywizacja Boga, lecz promulgowanie go jako kategorii metaprawnej ${ }^{163}$. Wydawać by się mogło, że ustrojodawca inkorporując pojęcie Boga do tekstu konstytucji, a niekiedy i określając jego przymioty, tym samym podejmuje się rozstrzygnięć z zakresu teologii co do istnienia Boga i jego natury ${ }^{164}$. Asocjacje takie nie są zasadne. Konstytucje poprzez odniesienie do Boga nie stają się zjurydyzowanymi traktatami teologicznymi.

Obecność invocatio czy nominatio Dei w ustawie zasadniczej generalnie należy ocenić aprobatywnie, ilekroć stanowią one przejaw responsywności ustrojodawcy wobec przekonań i wierzeń obywateli o Bogu. Ocena ta musiałaby ulec rewizji, gdyby ustrojodawca odniesieniami do Boga w tekście konstytucji nie tyle czynił zadość woli suwerena, ile instrumentalnie posługiwał się nimi jako narzędziem religijnej inżynierii społecznej i prozelityzmu. Podobnie krytycznie należy ustosunkować się do ideologicznie motywowanej niechęci ustrojodawcy do zamieszczenia odniesień do Boga w ustawie zasadniczej wbrew społecznym oczekiwaniom $^{165}$. Mówiąc o woli suwerena w praktyce, chodzi nolens volens o wolę społecznej większości. Naiwnym byłoby sądzić, że w kwestii konstytu-

163 Por. Domingo 2014.

164 Por. Brzozowski 2011, 111

${ }_{165}$ Zob. Joseph Weiler, Invocatio Dei and the European Constitution, https://www. project-syndicate.org/commentary/invocatio-dei-and-the-european-constitution?barrier=acc esspaylog [dostęp: 5.06.2019]. 
cyjnego invocatio i nominatio Dei uda się wypracować rozwiązania zadowalające wszystkich czy prawie wszystkich obywateli. W pluralistycznych społeczeństwach zarówno nadmienienie Boga w preambule ustawy zasadniczej, jak i jego w nim pominięcie posiada zwolenników i przeciwników.

Decyzja o zamieszczeniu, niezamieszczeniu lub usunięciu odwołania do Boga w konstytucji powinna stanowić wypadkową ewoluującej doniosłości sfery sacrum dla społeczeństwa. Odniesienia do Boga w ustawach zasadniczych zwykle, z wyłączeniem państw islamskich, mają charakter symboliczny, a nie typowo normatywny. Na poziomie „symboliki, retoryki i emblematów"166 od ustrojodawcy należy oczekiwać kierowania się wolą politycznego suwerena ${ }^{167}$. Niedemokratyczne byłoby niezamieszczenie invocatio Dei w konstytucji w opozycji do stanowiska społecznej większości. Z drugiej jednak strony osoby wierzące pragnące symbolicznego promulgowania Boga w konstytucji powinny uszanować odmowną decyzję ustrojodawcy - co nie oznacza podzielania jej merytorycznej trafności ilekroć ustrojodawca swoją decyzją uczynił zadość stanowisku większości obywateli (osób niewierzących lub wierzących przyjmujących prywatystyczną wizję religii).

Obecność lub nieobecność odniesień do Boga w konstytucji jest ważną kwestią, ale mimo wszystko wtórną wobec ochrony wolności sumienia i religii jednostki, tak w aspekcie pozytywnym (,wolność do"), jak i negatywnym (,wolność od”). Większym zagrożeniem dla integralności wierzących obywateli ${ }^{168}$ jest nie brak invocatio Dei w konstytucji, co ustawowe i sądowe dysproporcjonalne reglamentowanie postępowania zgodnego $\mathrm{z}$ ich wyznawaną wiarą ${ }^{169}$. Podobnie zagrożenia dla praw osób niewierzących nie tyle należy upatrywać w odwołaniu się do Boga w konstytucji, ile w postaci poszczególnych przepisów prawnych dotyczących wolności osobistej jednostki.

Nieuprawnione jest twierdzenie, że samo zamieszczenie odniesienia do Boga w konstytucji jest naruszeniem zasługujących na ochronę interesów osób niewierzących czy - w przypadku konfesyjnych invocatio

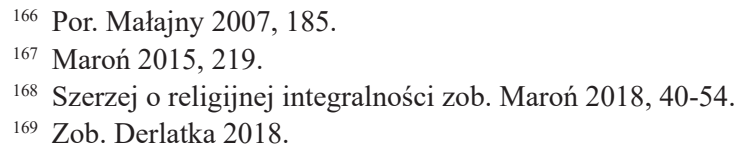


$D e i$ - interesów obywateli będących wyznawcami innych religii. Idąc tym mylnym tokiem rozumowania, należałoby konsekwentnie przyjąć, że brak invocatio Dei narusza z kolei prawa i wolności osób wierzących. Podobnie odwołanie do Boga w konstytucji nie musi godzić w światopoglądową bezstronność/neutralność państwa bardziej niż odmowa zamieszczenia w ustawie zasadniczej takiego odwołania ${ }^{170}$. Idea państwa światopoglądowo neutralnego w jego absolutystycznym rozumieniu jest kontrfaktyczna. Państwo nie może zachować pełnej symetrii, jak i indyferentności do różnych światopoglądów i systemów wartości. Nie jest to ani wykonalne, ani pożądane ${ }^{171}$.

Blisko półtora wieku temu Fryderyk Nieztsche obwieścił śmierć Boga (Gott is $t o t)^{172}$. Twierdzenie to tak wówczas, jak i obecnie pozostaje nieprawdziwe w tym sensie, iż wiara w Boga jest udziałem większości globalnej populacji. Szacuje się, że około 84 \% wszystkich ludzi uznaje się za osoby religijne, z czego zdecydowana większość to wyznawcy religii monoteistycznych i politeistycznych ${ }^{173}$. Głębokie procesy sekularyzacyjne zachodzące od dekad zwłaszcza w świecie Zachodnim nie mogą uchodzić za reprezentatywne w skali globalnej. Nawet jednak w odniesieniu do umownie określonych państw zachodnich procesy sekularyzacyjne współistnieją $\mathrm{z}$ coraz silniejszymi tendencjami desekularyzacyjnymi ${ }^{174}$.

Wiara w Boga nie zamyka się w sferze duchowości jednostki, lecz poprzez religię staje się faktem społeczno-kulturowym. Propagowana przez środowiska liberalne prywatyzacja religii, rozumiana w kategoriach nieemanowania jej poza sferę życia osobistego wierzącego, skazana jest na niepowodzenie, nawet jeśli cieszy się ona poparciem w szerokich kręgach liberalnych intelektualistów i pomimo jej internalizacji przez wielu wyznawców - głównie deklarujących się jako chrześcijanie - w państwach zachodnich. Legitymizacja prywatyzacji religii opiera się na przeświad-

170 Domingo 2016.

171 Łączkowski 2006, 211-212 i 218-219.

172 Fryderyk Nietzsche, Wiedza radosna (sekcja 108, 125 i 343).

173 Według danych z 2015 r. na świecie żyło 2,3 miliarda chrześcijan, 1,8 miliarda muzułmanów i 1,1 miliarda wyznawców hinduizmu. Harriet Sherwood, How many believers are there around the world? https://www.theguardian.com/news/2018/aug/27/religion-why-is-faith-growing-and-what-happens-next [dostęp: 5.06.2019].

174 Berger 2008; Mariański 2013. 
czeniu o „prywatnej i subiektywnej naturze religii" ${ }^{175}$. Tymczasem „,idea czysto prywatnej religii jest nie do pomyślenia, tak jak idea czysto prywatnego języka" ${ }^{176}$. Skoro religia jest rzeczywistością społeczno-kulturową, to czymś naturalnym wydaje się pragnienie wyznawców, aby to, w co oni wierzą znalazło swój wyraz, choćby symboliczny, czy przełożenie na postać porządku polityczno-prawnego. Czym większą grupę obywateli stanowią wierzący, tym większa ich zdolność, aby pragnieniu temu uczynić zadość. Szczególnym tego przejawem i potwierdzeniem jest inkorporowanie pojęcia Boga do konstytucji jako aktu normatywnego naznaczającego i profilującego porządek prawny danego państwa.

\section{BIBLIOGRAFIA}

Bała Paweł. 2010. Pod wezwaniem Boga czy Narodu? Religia a ustrój - studium przypadku polskich konstytucji. Warszawa: Wydawnictwo von Borowiecky.

Bała, Paweł. 2011. „Invocatio Dei w Konstytucji RP z 2 kwietnia 1997 r. w perspektywie porównawczej i historycznej”. Studia Erasmiana Wratislaviensia 5: 305-333.

Bar, Wiesław. 2004. „Kwestie wyznaniowe w konstytucjach Ameryki łacińskiej i Karaibów". W: Prawo wyznaniowe w systemie prawa polskiego. Materiaty I Ogólnopolskiego Sympozjum Prawa Wyznaniowego (Kazimierz Dolny, 14-16 stycznia 2003), 158-190, red. Artur Mezglewski. Lublin: Wydawnictwo KUL.

Berger, Peter. 2008. The Desecularization of the World: Resurgent Religion and World Politics. Washington: Ethics and Public Policy Center.

Borecki, Paweł. 2017. „Znamiona państwa wyznaniowego - uwagi na kanwie dorobku współczesnego konstytucjonalizmu". Studia z Prawa Wyznaniowego 20: 223-248.

Brining, Margaret, Steven Nock. 1999. „Convenant and Contract”. Regent University Law Review 12: 9-26.

Brzozowski, Wojciech. 2010. Bezstronność światopogladowa władz publicznych w Konstytucji RP. Warszawa: Wolters Kluwer.

175 Mack 1999, 484. José Casanova formułuje nawet tezę o deprywatyzacji religii, Casanova 2005.

176 Brining, Nock 1999, 23. 
Casanova, José. 2005. Religie publiczne w nowoczesnym świecie. Kraków: Zakład Wydawniczy Nomos.

Derlatka, Marek. 2018. „Konstytucyjność zakazu odmowy świadczenia z art. 138 k.w. - na marginesie postanowienia Sądu Najwyższego z dnia 14 czerwca 2018 r., sygn. II KK 333/17”. Prokuratura i Prawo 12: 119-124. Domingo, Rafael. 2014. „The Metalegal God”. Ecclesiastical Law Journal 16(2): 147-167.

Domingo, Rafael. 2016. God and the Secular Legal System. New York: Cambridge University Press.

Grześkowiak, Alicja. 1996. Imię Boga w Konstytucji. Częstochowa: Tygodnik Katolicki Niedziela.

Henry, Eron. 2018. Constitutionally Religious: What the Constitutions of 180 Countries Say About Religion and Belief. Alexandria: b.w.

Iban, Iván. 2013. „God in Constitutions and Godless Constitutions”. W: Law, Religion, Constitution: Freedom of Religion, Equal Treatment, and the Law, ed. Cole Durham, Ferrari Silvo, Cianitto Cristina, Thayer Donlu, 37-55. Farnham: Ashgate.

Krukowski, Józef. 1996. „«Invocatio Dei» w konstytucjach współczesnych państw demokratycznych. Refleksja w związku z debatą nad projektem Konstytucji RP”. Ethos: Kwartalnik Instytutu Jana Pawła II KUL 3/4: 202-214.

Łączkowski, Wojciech. 2006. „«Bezstronność» władz publicznych”. Ruch Prawniczy, Ekonomiczny i Socjologiczny 2: 209-219.

Mack, Michelle. 1999. „Religious Human Rights and the International Human Rights Community: Finding Common Ground - Without Compromise". Notre Dame Journal of Law, Ethics \& Public Policy 13(2): 455-497.

Małajny, Ryszard. 2007. „III Rzeczpospolita państwem quasi-wyznaniowym (10 lat obowiązywania konfesyjnych postanowień Konstytucji z 1997 r.)". W: Dziesięć lat Konstytucji Rzeczypospolitej Polskiej, red. Ewa Gdulewicz, Halina Zięba-Załucka, 184-199. Rzeszów: Wydawnictwo Uniwersytetu Rzeszowskiego.

Mariański, Janusz. 2013. Sekularyzacja. Desekularyzacja. Nowa duchowość. Studium socjologiczne. Kraków: Wydawnictwo Nomos.

Maroń, Grzegorz. 2012. „Instytucja przysięgi głowy państwa w państwach europejskich”. Przeglad Prawa Konstytucyjnego 1: 151-178.

Maroń, Grzegorz. 2014. „Bóg w polskim porządku prawnym”. Przegląd Prawa Wyznaniowego 6: 57-76.

Maroń, Grzegorz. 2015. „Responsywność porządku prawnego wobec tożsamości religijnej obywateli jako czynnik sprzyjający jego społecznej legitymizacji”. Przegląd Prawa Publicznego 7-8: 209-220. 
Maroń, Grzegorz. 2017. „Konstytucyjność aktów ceremonialnego deizmu w świetle orzecznictwa sądów USA". Przegląd Prawa Konstytucyjnego 3: 31-51.

Maroń, Grzegorz. 2018. Integralność religijna sędziego oraz argumentacja religijna $w$ amerykańskim procesie orzeczniczym. Rzeszów: Wydawnictwo Uniwersytetu Rzeszowskiego.

Neo, Jaclyn. 2017. „Express Recognition of Deity in Constitutions”. W: Max Planck Encyclopedia of Comparative Constitutional Law, ed. Rainer Grote, Frauke Lachenmann, Rüdiger Wolfrum. Oxford: Oxford University Press.

Nikołajew, Jerzy. 2015. „Konstytucja Islamskiej Republiki Iranu. Zagadnienia wyznaniowe". Nurt SVD 2: 191-212.

Schmid, Konrad. 2004. „In the Name of God? The Problem of Religious or Non-religious Preambles to State Constitutions in Post-atheistic Contexts". Religion in Eastern Europe 24: 19-32.

Temperman, Jeroen. 2010. State-Religion Relationships and Human Rights Law: Towards a Right to Religiously Neutral Governance. Leiden-Boston: Martinus Nijhoff Publishers.

\section{ZAŁĄCZNIK A}

WYKAZ KONSTYTUCJI ZAWIERAJĄCYCH ODNIESIENIA DO BOGA WRAZ ZE WSKAZANIEM ICH PEŁNYCH TEKSTÓW (data dostępu we wszystkich przypadkach: 5.06.2019).

\section{Konstytucje:}

Islamskiej Republiki Afganistanu z 4 stycznia 2004 r. http://moj.gov.af/fa/page/ legal-frameworks/168329941684

Republiki Albanii z 21 października 1998 r. http://www.pp.gov.al/web/kushtetuta 2016_1082.pdf. Tłum. Dorota Horodyska, Edlira Lloha. 2001. Warszawa: Wydawnictwo Sejmowe. http://libr.sejm.gov.pl/tek01/txt/konst/albania98.html

Algierskiej Republiki Ludowo-Demokratycznej z 28 listopada 1996 r. http:// www.premier-ministre.gov.dz/ressources/front/files/pdf/texts-fondamentaux/ nouvelle-constitution-2016-arabe.pdf

Antiguy i Barbudy z 31 lipca 1981 r. http://laws.gov.ag/wp-content/uploads/2018/08/cap-23.pdf

Królestwa Arabii Saudyjskiej z 1 marca 1992 r. https://laws.boe.gov.sa/BoeLaws/ Laws/LawDetails/16b97fcb-4833-4f66-8531-a9a700f161b6/1 Republiki Argentyńskiej z 1 maja 1853 r. http://www.saij.gob.ar/nacional-constitucion- 
-nacional-constitucion-nacion-argentina-lns0002665-1994-08-22/123456789 -0abc-defg-g56-62000scanyel

Związku Australijskiego z 9 lipca 1900 r. https://www.aph.gov.au/About_Parliament/Senate/Powers_practice_n_procedures/Constitution.aspx. Tłum. Jan Winczorek. 2014. Warszawa: Wydawnictwo Sejmowe. http://biblioteka.sejm.gov.pl/ wp-content/uploads/2015/05/Australia_pol010714.pdf

Wspólnoty Bahamów z 20 czerwca 1973 r. http://www.bahamas.gov.bs/wps/portal/ public/About\%20The\%20Bahamas/Constitution/!ut/p/b1/vZL LkqIwFlafxQeYJuESYBIFEIFwv24oQRu8BFQQhacfe2bTM1XdvZmeZJWqL-c_38OkzEJkzWbYV9t-n3bbE5v7wzlHNAsjHnJ0gSAgB46JnbEFWtDgYmZJEjZh9LplaZ7r2e3O2DvrKOoJltFv5k3uK8cvqd4QXInER6hYMuQu5VdScmVLjWuZZcNEhNBbJo59pc1ugw1CXdN3V6HU5AEo_6EDruuhJIKGqUr Qw-ievUwlsXoGWXX-7Ui6ihqaTmSJ1drCApZVUYq_aM6m4b3nqULm-gO6kXNStAYbeJZCXyDsyFajZ7GkyfBsEHB4Ov_P_-_xHAg6_zyz5F3ir8Aj5r8d MKBsukT0B8BwQRADoE2POhCyQCmYBJAJ_7h_GsT8fJO4A7S8wSWIrnwCOAQVBEJNBGi6yJf_UsGILJD7K1NbmwO1ZjTwJnG3nhHCt4A8Phb0GbDeSn4AIiIxSAD_jvFtQEW3pGIAYOFlig2fB_C3L_NVLNscG3O_xjaXj3389wzWT7gr7cS_oCXiQZQUGUeFlCgOclkYkOKS8qkn5X 9CBftP1q08nd3D3GS9wrKDVLst97tC19WdLyteCfltUQNOWPeJAsQ4TtUdQX-EyP10CzTXi6VexresNp0tpoYde7MFJV5dr4VRMvZKpeRmz2rwc-V0gVTjFSPZYgwK6nnI4-KnpfKhzpQEtRbaYsnYxE11PquvwDuPlp24VHYMRdUppO1XJauaU9ApXvFPUqqkA0HJoaXVdjFm_GguXFk4Q5Vhc3 Iwhq5bumDMdDBN5qyl5d3d49hMFKvZa/d14/d5/L2dBISEvZ0FBIS9nQSEh/

Królestwa Bahrajnu z 14 lutego 2002 r. http://www.legalaffairs.gov.bh/LegislationSearchDetails.aspx?id=2670\#.XStpUnswiUk

Ludowej Republiki Bangladeszu z 4 listopada 1972 r. http://bdlaws.minlaw.gov. bd/bangla_pdf_part.php?id=957

Barbadosu z 30 listopada 1966 r. https://barbados.org/constitution.htm

Belize z 21 września 1981 r. http://www.nationalassembly.gov.bz/wp-content/ uploads/2017/03/Belize-Constitution-2017updated-March.pdf

Republiki Beninu z 11 grudnia 1990 r. http://www.cour-constitutionnelle-benin. org/lacourpresent/decrets/Constitution.pdf

Królestwa Bhutanu z 18 lipca 2008 r. http://www.nab.gov.bt/dz/business/constitution_of_bhutan

Wielonarodowego Państwa Boliwii z 25 stycznia 2009 r. http://www.presidencia. gob.bo/documentos/publicaciones/constitucion.pdf

Brunei Darussalam z 29 września 1959 r. http://www.agc.gov.bn/AGC\%20Images/ LOB/cons_doc/constitution_i.pdf 
Federacyjnej Republiki Brazylii z 5 października 1988 r. http://www.planalto. gov.br/ccivil_03/Constituicao/Constituicao.htm Tłum. Agnieszka Wojtyczek-Bonnand. 2004. Warszawa: Wydawnictwo Sejmowe. http://biblioteka.sejm. gov.pl/konstytucje-swiata-brazylia/?lang=en

Republiki Chile z 11 września 1980 r. https://www.leychile.cl/Navegar?idNorma $=242302$ Tłum. Agnieszka Wojtyczek-Bonnand. 2012. Warszawa: Wydawnictwo Sejmowe. http://libr.sejm.gov.p1/tek01/txt/konst/chile2013.pdf

Królestwa Danii z 5 czerwca 1953 r. https://www.ft.dk/ /media/sites/ft/pdf/publikationer/grundloven/grundloven_samlet_2018_dk_web.ashx Tłum. Marian Grzybowski. 2011. W: Konstytucje państw Unii Europejskiej, red. Wiesław Staśkiewicz, 213-225. Warszawa: Wydawnictwo Sejmowe. http://biblioteka. sejm.gov.pl/wp-content/uploads/2015/07/Dania_pol_010811.pdf

Republiki Dominikany z 13 czerwca 2015 r. http://www.senado.gob.do/senado/

$\mathrm{OAI} /$ Constitucion.aspx

Wspólnoty Dominiki z 25 lipca 1978 r. http://www.dominica.gov.dm/laws/chapters/chap1-01-sch1.pdf

Republiki Dżibuti z 15 września 1992 r. https://www.presidence.dj/TexteFond.php Republiki Ekwadoru z 20 października 2008 r. https://www.asambleanacional.gob.

$\mathrm{ec} / \mathrm{sites} / \mathrm{default} / \mathrm{files} / \mathrm{private} /$ asambleanacional/filesasambleanacionalnameuid-20/transparencia-2015/literal-a/a2/Const-Enmienda-2015.pdf

Arabskiej Republiki Egiptu z 18 stycznia 2014 r. http://www.egypt.gov.eg/arabic/ laws/default.aspx

Republiki Fidżi z 6 września 2013 r. https://www.fiji.gov.fj/About-Fiji/Fijian-Constitution

Republiki Filipin z 2 lutego 1987 r. http://www.officialgazette.gov.ph/constitutions/ 1987-constitution/

Republiki Gabońskiej z 26 marca 1991 r. http://www.assemblee-nationale.ga/36-connaitre-1-assemblee-nationale/76-la-constitution-/

Republiki Gambii z 16 stycznia 1997 r. http://assembly.gov.gm/wp-content/uploads/2016/12/CONSTITUTION-OF-THE-GAMBIA-1997.pdf

Republiki Ghany z 28 kwietnia 1992 r. https://www.judicial.gov.gh/index.php/ preamble

Republiki Greckiej z 9 czerwca 1975 r. https:/www.hellenicparliament.gr/ UserFiles/8c3e9046-78fb-48f4-bd82-bbba28ca1ef5/SYNTAGMA.pdf. Tłum. Grażyna i Włodzimierz Uliccy, Bartłomiej Zdaniuk, Natalia Ciesielczyk. 2011. W: Konstytucje państw Unii Europejskiej, red. Wiesław Staśkiewicz, 297-340. Warszawa: Wydawnictwo Sejmowe. http://biblioteka.sejm.gov.pl/ wp-content/uploads/2015/07/Dania_pol_010811.pdf 
Grenady z 19 grudnia 1973 r. https://www.gov.gd/egov/docs/legislations/constitution/grenada_constitution_order_1973.pdf

Gruzji z 24 sierpnia 1995 r. https://matsne.gov.ge/ka/document/view/30346? publication=35. Thum. Grzegorz Kuca, Marian Grzybowski, Katarzyna Kaczmarczyk-Kłak.2015.Warszawa:WydawnictwoSejmowe.http://biblioteka.sejm.gov.pl/ wp-content/uploads/2016/01/Gruzja_pol_010715.pdf

Kooperacyjnej Republiki Gujany z 20 lutego 1980 r. http://parliament.gov.gy/constitution.pdf

Republiki Gwatemali z 31 maja 1985 r. https:/guatemala.justia.com/nacionales/ constitucion-de-la-republica-de-guatemala/

Republiki Gwinei Równikowej z 16 listopada 1991 r. https://www.guineaecuatorialpress.com/imgdb/2012/LEYFUNDAMENTALREFORMADA.pdf

Republiki Haiti z 10 marca 1987 r. http://www.omrh.gouv.ht/Media/Publications/1-Constitution/Constitution1987Amend\%C3\%A9eJuin2012.pdf

Republiki Hondurasu z 11 stycznia 1982 r. http://www.congreso.gob.hn/constitucionVigentes.htm

Republiki Indii z 26 listopada 1949 r. https://www.india.gov.in/hi/my-government/ constitution-india/constitution-india-full-text

Republiki Indonezji z 1 czerwca 1945 r. http://www.dpr.go.id/jdih/uu1945

Republiki Iraku z 15 października 2005 r. http://ar.parliament.iq/\%D8\%A7\%D9\% 84\%D8\%AF\%D8\%B3\%D8\%AA\%D9\%88\%D8\%B1-\%D8\%A7\%D9\%84\% D8\%B9\%D8\%B1\%D8\%A7\%D9\%82\%D9\%8A/

Islamskiej Republiki Iranu z 24 października 1979 r. https://www.parliran.ir/majles/fa/Content/articles-6739/\%d9\%82\%d8\%a7\%d9\%86\%d9\%88\%d9\%86-\%d8\%a7\%d8\%b3\%d8\%a7\%d8\%b3\%db\%8c-\%d8\%ac\%d9\%85\%d9\%87 \%d9\%88\%d8\%b1\%db\%8c-\%d8\%a7\%d8\%b3\%d9\%84\%d8\%a7\%d9\%85 $\% \mathrm{db} \% 8 \mathrm{c}-\% \mathrm{~d} 8 \% \mathrm{a} 7 \% \mathrm{db} \% 8 \mathrm{c} \% \mathrm{~d} 8 \% \mathrm{~b} 1 \% \mathrm{~d} 8 \% \mathrm{a} 7 \% \mathrm{~d} 9 \% 86-13960605$

Republiki Irlandii z 1 lipca 1937 r. https://www.gov.ie/en/publication/d5bd8c-constitution-of-ireland/ Tłum. Sabina Grabowska. 2011. W: Konstytucje państw Unii Europejskiej, red. Wiesław Staśkiewicz, 393-417. Warszawa: Wydawnictwo Sejmowe.

Jamajki z 24 lipca 1962 r. https://jis.gov.jm/media/Ja-Constitution-Order-in-Council-1962-full.pdf

Republiki Jemeńskiej z 16 maja 1991 r. http://www.yemen.gov.ye/portal/\%D8\%A7 \%D9\%84\%D8\%AC\%D9\%85\%D9\%87\%D9\%88\%D8\%B1\%D9\%8A\%D8\% A9\%D8\%A7\%D9\%84\%D9\%8A\%D9\%85\%D9\%86\%D9\%8A\%D8\%A9/\% D8\%A7\%D9\%84\%D8\%AF\%D8\%B3\%D8\%AA\%D9\%88\%D8\%B1\%D8\% A7\%D9\%84\%D9\%8A\%D9\%85\%D9\%86\%D9\%8A/tabid/2618/Default.aspx 
Jordańskiego Królestwa Haszymidzkiego z 11 stycznia 1952 r. http://cco.gov.jo/ portals/0/cconew.pdf

Kanady (in concreto Akt konstytucyjny z 17 kwietnia 1982 r.) https://laws-lois. justice.gc.ca/eng/Const/index.html; https://lois-laws.justice.gc.ca/fra/const/. Tłum. Joachim Osiński, Izabela Zawiślińska. 1998. Warszawa: Wydawnictwo Sejmowe. http://biblioteka.sejm.gov.pl/wp-content/uploads/2016/01/Kanada_ pol_010496.pdf

Kataru z 29 kwietnia 2003 r. http://www.almeezan.qa/LawPage.aspx?id=2284 \&language $=$ ar

Republiki Kenii z 27 sierpnia 2010 r. http://www.kenyalaw.org:8181/exist/rest// $\mathrm{db} /$ kenyalex/Kenya/The\%20Constitution\%20of\%20Kenya/docs/ConstitutionofKenya\%202010.pdf Tłum. Błażej Popławski, Piotr Zakrzewski. 2017. Warszawa: Wydawnictwo Sejmowe. http://biblioteka.sejm.gov.pl/wp-content/ uploads/2017/09/Kenia_pol_010117.pdf

Republiki Kolumbii z 4 lipca 1991 r. http://www.suin-juriscol.gov.co/viewDocument.asp?ruta $=$ Constitucion $/ 1687988$

Związku Komorów z 23 grudnia 2001 r. http://mjp.univ-perp.fr/constit/km2009.htm

Demokratycznej Republiki Konga z 18 lutego 2006 r. http://www.senat.cd/images/ Constitution_de_la_RDC.pdf

Republiki Kostaryki z 8 listopada 1949 r. http://www.pgrweb.go.cr/scij/Busqueda/ Normativa/Normas/nrm_norma.aspx?param $1=$ NRM \&nValor $1=1 \& n$ Valor $2=$ $871 \&$ nValor3 $=95479 \&$ strTipM=FN

Państwa Kuwejt z 11 listopada 1962 r. http://www.pm.gov.kw/kuwait-constitution-ar.aspx

Królestwa Lesotha z 2 kwietnia 1993 r. http://www.parliament.ls/senate/joomdocs/ lesotho_constitution.pdf

Republiki Libanu z 23 maja 1926 r. https://www.lp.gov.lb/backoffice/uploads/file s/\%D8\%A7\%D9\%84\%D8\%AF\%D8\%B3\%D8\%AA\%D9\%88\%D8\%B1\%20 \%D8\%A7\%D9\%84\%D9\%84\%D8\%A8\%D9\%86\%D8\%A7\%D9\%86\%D9\% 8A(1).pdf

Republiki Liberii z 6 stycznia 1986 r. http://www.necliberia.org/content/legaldocs/ laws/theconstitution.pdf

Libii z 3 sierpnia 2011 r. http://itcadel.gov.ly/wp-content/uploads/pdfs2013/ add01-2015.pdf

Księstwa Lichtensteinu z 5 października 1921 r. https://www.gesetze.li/konso/ 1921015000. Tłum. Radosław Grabowski. 2013. Warszawa: Wydawnictwo Sejmowe. http://biblioteka.sejm.gov.pl/wp-content/uploads/2016/01/Liechtenstein_pol_010712.pdf 
Republiki Litewskiej z 25 października 1992 r. (in concreto Ustawa Republiki Litewskiej o trybie wejścia w życie Konstytucji Republiki Litewskiej). http:// www3.lrs.lt/home/Konstitucija/Konstitucija.htm. Tłum. Henryk Wisner. 2011. W: Konstytucje państw Unii Europejskiej, red. Wiesław Staśkiewicz, 419-442. Warszawa: Wydawnictwo Sejmowe.

Republiki Łotewskiej z 15 lutego 1922 r. https://likumi.lv/doc.php?id=57980. Tłum. Lidia Gołubiec, Iwona Jaroszkiewicz. 2011. W: Konstytucje państw Unii Europejskiej, red. Wiesław Staśkiewicz, 459-470. Warszawa: Wydawnictwo Sejmowe. http://biblioteka.sejm.gov.pl/wp-content/uploads/2016/11/ Lotwa_pol_010711.pdf

Republiki Madagaskaru z 11 grudnia 2010 r. http://www.hcc.gov.mg/wp-content/ uploads/2015/09/CONSTITUTION-IV.pdf

Republiki Malawi z 16 maja 1994 r. http://www.sdnp.org.mw/constitut/dtlindx.html Republiki Malediwów z 7 sierpnia 2008 r. http://www.maldivesinfo.gov.mv/home/ upload/downloads/constitution.pdf

Malezji z 31 sierpnia 1957 r. http://www.jac.gov.my/images/stories/akta/perlembagaanpersekutuan.pdf

Republiki Mali z 25 lutego 1992 r. http://www.gouv.ml/NWPM/front/CmsContentView.do?bId=36\&MENU_SEQ=55\&MENU_TYPE=1 Republiki Malty z 21 września 1964 r. http://www.justiceservices.gov.mt/DownloadDocument. aspx?app=lom\&itemid=8566\&l=2. Tłum. Jan Winczorek. 2011. W: Konstytucje państw Unii Europejskiej, red. Wiesław Staśkiewicz, 471-518. Warszawa: Wydawnictwo Sejmowe. http://biblioteka.sejm.gov.pl/wp-content/uploads/2016/02/Malta_pol_010711.pdf

Królestwa Maroka z 29 listopada 2011 r. http://www.sgg.gov.ma/Portals/0/ constitution/constitution_2011_Fr.pdf; http://www.sgg.gov.ma/Portals/1/lois/ constitution_2011_Ar.pdf. Tłum. Tatiana Chauvin. 2015. Warszawa: Wydawnictwo Sejmowe. http://biblioteka.sejm.gov.pl/wp-content/uploads/2015/09/ Maroko_pol_010115.pdf

Islamskiej Republiki Mauretanii z 12 lipca 1991 r. http://biblioteka.sejm.gov.pl/ wp-content/uploads/2017/07/Mauretania_ar_010117.pdf

Republiki Mauritiusa z 12 marca 1968 r. http://mauritiusassembly.govmu.org/English/constitution/Pages/constitution2016.pdf

Republiki Nauru z 31 stycznia 1968 r. http://www.naurugov.nr/parliament-of-nauru/constitution-of-nauru.aspx

Republiki Federalnej Niemiec z 23 maja 1949 r. https://www.bundestag.de/bundestag/aufgaben/rechtsgrundlagen/grundgesetz/index.html. Tłum. Bogusław Banaszak, Agnieszka Malicka. 2011. W: Konstytucje państw Unii Europejskiej, red. Wiesław Staśkiewicz, 519-564. Warszawa: Wydawnictwo Sej- 
mowe. http://biblioteka.sejm.gov.pl/wp-content/uploads/2016/02/Niemcy_ pol_010711.pdf

Republiki Nigru z 31 października 2010 r. http://cour-constitutionnelle-niger.org/ documents/constitution_7eme_rep.pdf

Federalnej Republiki Nigerii z 29 maja 1999 r. http://www.nigeria-law.org/ConstitutionOfTheFederalRepublicOfNigeria.htm

Republiki Nikaragui z 19 listopada 1986 r. http://legislacion.asamblea.gob.ni/Normaweb.nsf/xpNorma.xsp?documentId=C93CBD0FF408D07306257C8C004 F6953\&action=openDocument

Królestwa Norwegii z 17 maja 1814 r. https://lovdata.no/dokument/NL/lov/1814-05-17. Tłum. Joachim Osiński. 1996. Warszawa: Wydawnictwo Sejmowe. http://biblioteka.sejm.gov.pl/konstytucje-swiata-norwegia/

Nowej Zelandii (in concreto Traktat z Waitangi z 1840 r., Ustawa o tytułach królewskich z 1974 r., Patent królewski ustanawiający Urząd Gubernatora Generalnego Nowej Zelandii z 1983 r.) https://dpmc.govt.nz/our-business-units/ cabinet-office/supporting-work-cabinet/cabinet-manual/introduction. Tłum. Łukasz Jakubiak. 2018. Warszawa: Wydawnictwo Sejmowe. http://biblioteka. sejm.gov.pl/wp-content/uploads/2019/02/Nowa_Zelandia_pol_010117.pdf

Sułtanatu Omanu z 6 listopada 1996 r. http://mola.gov.om/basicstatute.aspx

Islamskiej Republiki Pakistanu z 14 sierpnia 1973 r. www.na.gov.pk/uploads/documents/1391139448_469.pdf; www.na.gov.pk/en/downloads.php

Republiki Panamy z 11 października 1972 r. http://www.asamblea.gob.pa/constituciones/

Niezależnego Państwa Papui Nowej Gwinei z 16 sierpnia 1975 r. http://www.parliament.gov.pg/constitution-of-the-independent-state-of-papua-new-guinea

Republiki Paragwaju z 20 czerwca 1992 r. www.mre.gov.py/v2/Adjuntos/Normativas/CONSTITUCIONNACIONAL.pdf

Republiki Peru z 29 grudnia 1993 r. http://www.leyes.congreso.gob.pe/Documentos/constituciones_ordenado/CONSTIT_1993/Texto_actualizado_ CONS_1993.pdf

Republiki Południowej Afryki z 8 maja 1996 r. http://www.justice.gov.za/legislation/constitution/index.html. Tłum. Agnieszka Wojtyczek-Bonnand, Krzysztof Wojtyczek. 2006. Warszawa: Wydawnictwo Sejmowe http://biblioteka. sejm.gov.pl/wp-content/uploads/2016/03/RPA.pdf

Republiki Środkowo-Afrykańskiej z 20 marca 2016 r. http://www.assembleenationale-rca.cf/wp-content/uploads/2017/07/PROPOSITION_DE_CONSTITUTION_CENTRAFRIQUE_mars_2017.pdf

Rumunii z 21 listopada $1991 \mathrm{r}$. http://www.cdep.ro/pls/dic/site.page?id=371\&idl=1. Tłum. Andrzej Cosma. 2011. W: Konstytucje państw Unii Europejskiej, red. 
Wiesław Staśkiewicz, 665-692. Warszawa: Wydawnictwo Sejmowe. http://biblioteka.sejm.gov.pl/wp-content/uploads/2016/03/Rumunia_pol_010711.pdf Republiki Rwandy z 4 czerwca 2003 r. http://www.parliament.gov.rw/fileadmin/

Bills_CD/THE_CONSTITUTION_OF_THE_REPUBLIC_OF_RWANDA_ OF_2003_REVISED_IN_2015.pdf

Rzeczypospolitej Polskiej z 2 kwietnia 1997 r., Dz. U. z 1997 r. Nr 78, poz. 483 z późn. zm.

Federacji Saint Kitts i Nevis z 22 czerwca 1983 r. https://nia.gov.kn/documents/ constitution/

Saint Lucia z 22 lutego 1978 r. http://www.govt.lc/constitution

Saint Vincent i Grenadyny z 26 lipca 1979 r. http://www.gov.vc/images/visitors/1979_constitution.pdf

Republiki Salwadoru z 15 grudnia 1983 r. http://www.jurisprudencia.gob.sv/ busqueda/showFile.php?bd=2\&data=DocumentosBoveda $\% 252 \mathrm{FD} \% 252 \mathrm{~F} 2$ $\% 252 \mathrm{~F} 1980-1989 \% 252 \mathrm{~F} 1983 \% 252 \mathrm{~F} 12 \% 252 \mathrm{~F} 886 \mathrm{EF}$.PDF \&number $=5588$ $31 \&$ fecha $=16 \% 2 \mathrm{~F} 12 \% 2 \mathrm{~F} 1983 \&$ numero $=$ CONSTITUCION\%3DDE $\% 3 \mathrm{DL}$ A\%3DREPUBLICA\%3DDE\%3DEL\%3DSALVADOR\%3D(1983)\&single Page $=$ false

Niezależnego Państwa Samoa z 28 października 1960 r. http://www.palemene.ws/ new/constitution-and-standing-order/

Republiki San Marino (in concreto statuty z 8 października 1600 r.) https://www. consigliograndeegenerale.sm/on-line/home/archivio-leggi-decreti-e-regolamenti/scheda17009068.html

Republiki Senegalu z 22 stycznia 2001 r. http://www.jo.gouv.sn/spip.php?article36 Republiki Seszele z 18 czerwca 1993 r. http://www.gov.sc/documents/Constitution $\% 20$ of $\% 20$ Seychelles\%20.pdf

Republiki Sierra Leona z 3 września 1993 r. http://www.parliament.gov.sl/dnn5/ AboutUs/ConstitutionofSierraLeone.aspx

Federalnej Republiki Somalii z 1 sierpnia 2012 r. http:/www.parliament.gov.so/ images/Downloads/Dastuurka_ku_meelgaarka_SOM_03092012-1_2.pdf

Królestwa Suazi z 26 lipca 2005 r. http://www.gov.sz/images/stories/Constitution $\% 20$ of $\% 20 \% 20$ SD-2005A001.pdf

Republiki Sudanu z 6 lipca 2005 r. https://mofa.gov.sd/more.php?main_id=8\&sub_ $\mathrm{id}=31 \& \mathrm{id}=23$

Republiki Sudanu Południowego z 9 lipca 2011 r. http://www.sudantribune.com/ IMG/pdf/The_Draft_Transitional_Constitution_of_the_ROSS2-2.pdf

Republiki Surinamu z 30 września 1987 r. http://www.suriname.nu/101alg/grondwet01.html 
Syryjskiej Republiki Arabskiej z 26 lutego 2012 r. http://www.mod.gov.sy/index. php? node $=551 \&$ cat $=3858$

Federalnej Konfederacji Szwajcarskiej z 18 kwietnia 1999 r. https://www.admin. ch/opc/de/classified-compilation/19995395/index.html. Tłum. Zdzisław Czeszejko-Sochacki, 2000. Warszawa: Wydawnictwo Sejmowe. http://libr.sejm. gov.pl/tek01/txt/konst/szwajcaria.html

Królestwa Szwecji (in concreto Akt o sukcesji z 26 września 1810 r.) https:// www.riksdagen.se/sv/dokument-lagar/dokument/svensk-forfattningssamling/ successionsordning-18100926_sfs-1810-0926. Tłum. Krzysztof Dembiński, Marian Grzybowski. 2011. W: Konstytucje państw Unii Europejskiej, red. Wiesław Staśkiewicz, 749-816. Warszawa: Wydawnictwo Sejmowe. http:// biblioteka.sejm.gov.pl/wp-content/uploads/2016/04/Szwecja_pol_010711.pdf

Demokratycznej Republiki Timoru Wschodniego z 22 marca 2002 r. http://timor-leste.gov.tl/?cat=37\&lang=tp; http://timor-leste.gov.tl/?cat=37\&lang=pt

Republiki Togo z 27 września 1992 r. http://legitogo.gouv.tg/home

Królestwa Tonga z 4 listopada 1875 r. https://www.parliament.gov.to/parliamentary-business/documents/constitution-of-tonga

Republiki Trynidadu i Tobago z 24 marca 1976 r. http://rgd.legalaffairs.gov.tt/ Laws2/Constitution.pdf

Republiki Tunezji z 26 stycznia 2014 r. http://rgd.legalaffairs.gov.tt/Laws2/Constitution.pdf

Tuvalu z 1 października 1986 r. www.tuvaluislands.com/const_tuvalu.htm Republiki Ugandy z 8 października 1995 r. http://statehouse.go.ug/sites/default/ files/attachments/Constitution_1995.pdf

Ukrainy z 28 czerwca 1996 r. https://zakon2.rada.gov.ua/laws/show/254\%D0\% BA/96-\%D0\%B2\%D1\%80. Tłum. Ewa Toczek, Andrzej Kubik, Jarosław Turłukowski. 2018. Warszawa: Kancelaria Sejmu. http://biblioteka.sejm.gov. pl/wp-content/uploads/2018/02/Ukraina_pol_010118-1.pdf

Republiki Vanuatu z 23 października 1979 r. https://parliament.gov.vu/index. $\mathrm{php} / \mathrm{icons}$

Watykanu (in concreto Ustawa Zasadnicza Państwa Miasto Watykan z 26 listopada 2000 r.) http://www.vatican.va/news_services/press/documentazione/documents/sp_ss_scv/informazione_generale/legge-fondamentale_it.html. Tłum. Franciszek Longchamps de Bérier, Marek Zubik. 2008. W: Ustawa Zasadnicza Państwa Miasto Watykan oraz inne akty ustrojowe. Warszawa: Wydawnictwo Sejmowe. http://biblioteka.sejm.gov.pl/wp-content/uploads/2016/04/ Watykan_pol_010116.pdf

Boliwariańskiej Republiki Wenezueli z 20 grudnia 1999 r. http://www.cne.gob.ve/ web/normativa_electoral/constitucion/indice.php 
Węgier z 18 kwietnia 2011 r. https://www.parlament.hu/irom39/02627/02627-0187. pdf. Tłum. Jerzy Snopek. 2015. Warszawa: Wydawnictwo Sejmowe. http://biblioteka.sejm.gov.pl/wp-content/uploads/2016/12/Wegry_2016-popr.pdf

Republiki Wysp Marshalla z 1 maja 1979 r. https://rmiparliament.org/cms/images/

LEGISLATION/PRINCIPAL/1979/1979-0000/ConstitutionoftheRepublicoftheMarshallIslands_1.pdf

Wysp Salomona z 8 czerwca 1978 r. http://www.parliament.gov.sb/files/business \&procedure/constitution.htm

Republiki Zambii z 30 sierpnia 1991 r. http://www.parliament.gov.zm/sites/default/files/documents/amendment_act/Constitution $\% 20 \mathrm{of} \% 20 \mathrm{Zambia} \% 20$ \%20\%28Amendment\%29\%2C\%202016-Act\%20No.\%202_0.pdf

Republiki Zimbabwe z 9 maja 2013 r. https://www.parlzim.gov.zw/component/k2/ download/1290_da9279a81557040d47c3a2c27012f6e1.

Zjednoczonych Emiratów Arabskich z 2 grudnia 1971 r. http://rakpp.rak.ae/ar/Pag es/\%D8\%AF\%D8\%B3\%D8\%AA\%D9\%88\%D8\%B1-\%D8\%A7\%D9\%84\% D8\%A7\%D9\%85\%D8\%A7\%D8\%B1\%D8\%A7\%D8\%AA.aspx

Zjednoczonego Królestwa Wielkiej Brytanii i Irlandii Północnej (in concreto Wielka Karta Wolności z 1215 i 1297 r., Bill of Rights z 1689 r., Akt o sukcesji tronu z 1700 r.) http://www.legislation.gov.uk/all?title=bill\%20of\%20rights. Tłum. Sebastian Kubas. 2010. W: Konstytucje państw Unii Europejskiej, red. Wiesław Staśkiewicz, 871-976. Warszawa: Wydawnictwo Sejmowe. http://biblioteka.sejm.gov.pl/wp-content/uploads/2016/04/Wielka-Brytania_ pol_010711.pdf

\section{REFERENCES TO GOD IN THE CONSTITUTIONS OF CONTEMPORARY STATES. A COMPARATIVE STUDY}

\section{Summary}

The article presents the results of a quantitative and qualitative comparative study of the presence of direct references to God in the constitutions of modern states. References to God appearing in the fundamental laws of nearly two-thirds of the countries of the world differ in their linguistic forms and functions they perform. Most often, they take the form of an invocatio or nominatio Dei in preambles and appear in oaths of office, while they are less frequently included in other constitutional provisions such as those defining official state symbols - national flags, national anthems or emblems. References to God in the fundamental laws do not have a theological dimension, but they are a manifestation of legislators' 
responsiveness to the convictions and beliefs of citizens about God. In the author's opinion, the decision to include, not include or remove a reference to God in a constitution should follow from the evolving importance of the sphere of sacrum for the society of a given state as a political sovereign.

Key words: God; constitution; comparative method; cultural dimension of law; Law on Religion; Constitutional Law; axiology of law

Ttumaczenie własne autora 